NBER WORKING PAPER SERIES

\title{
TRADE, INEQUALITY, AND POVERTY: WHAT DO WE KNOW? EVIDENCE FROM RECENT TRADE LIBERALIZATION EPISODES IN DEVELOPING COUNTRIES
}

\author{
Pinelopi Koujianou Goldberg \\ Nina Pavcnik \\ Working Paper 10593 \\ http://www.nber.org/papers/w10593
NATIONAL BUREAU OF ECONOMIC RESEARCH
1050 Massachusetts Avenue
Cambridge, MA 02138
June 2004

The views expressed herein are those of the author(s) and not necessarily those of the National Bureau of Economic Research.

(C)2004 by Pinelopi Koujianou Goldberg and Nina Pavcnik. All rights reserved. Short sections of text, not to exceed two paragraphs, may be quoted without explicit permission provided that full credit, including (C) notice, is given to the source. 
Trade, Inequality, and Poverty: What Do We Know? Evidence from Recent Trade Liberalization Episodes in Developing Countries

Pinelopi Koujianou Goldberg and Nina Pavcnik

NBER Working Paper No. 10593

June 2004

JEL No. F13, F14, F16, J31

\title{
ABSTRACT
}

We review the empirical evidence on the relationship between Trade Liberalization, Inequality, and Poverty based on the analysis of micro data from several developing countries that underwent significant trade reforms in recent years. Despite many measurement and identification difficulties, and despite conflicting evidence on some issues, empirical work based on "country case studies" has established certain patterns that seem common across countries and trade liberalization episodes, and may hence be informative as to how developing countries adjust to trade reform.

\author{
Pinelopi Koujianou Goldberg \\ Department of Economics \\ Yale University \\ 37 Hillhouse Avenue \\ P.O. Box 208264 \\ New Haven, CT 06520-8264 \\ and NBER \\ penny.goldberg@yale.edu \\ Nina Pavcnik \\ Department of Economics \\ 6106 Rockefeller Center \\ Dartmouth College \\ Hanover, NH 03755 \\ and NBER \\ nina.pavcnik@dartmouth.edu
}




\section{Trade, Inequality, and Poverty: What Do We Know? Evidence from Recent Trade Liberalization Episodes in Developing Countries ${ }^{*}$}

\author{
Pinelopi Koujianou Goldberg \\ Department of Economics \\ Yale University \\ and NBER \\ Penny.Goldberg@yale.edu
}

\author{
Nina Pavcnik \\ Department of Economics \\ Dartmouth College \\ CEPR and NBER \\ Nina.Pavcnik@Dartmouth.edu
}

This draft: June 8, 2004

\section{Introduction}

The relationship between "globalization" and "inequality" or "poverty" has received considerable attention in recent years. The number of literature reviews alone is so large by now, that it seems that a review of literature reviews would be appropriate. Some common themes that emerge from this literature are: (a) globalization is a catch-all term that is used to describe phenomena as diverse as trade liberalization, outsourcing, increased immigration flows, removal of capital controls, cultural globalization, and generally faster transmission of international shocks and trends; (b) operational definitions of both "inequality" and "poverty" are associated with substantial conceptual and measurement problems; and (c) the evidence on the relationship between globalization and income inequality/poverty is mixed and related empirical findings are subject to varying interpretations.

Given this state of affairs, we would like to start this piece by clarifying how its focus will differ from previous surveys. Our primary goal is to cover those aspects of the relationship

\footnotetext{
* This paper was prepared for the 2004 Brookings Trade Forum on "Globalization, Poverty \& Inequality: What Do We Know? Where Are We Going?” held in Washington, DC, May 13-14, 2004. We are grateful to Susan Collins, Eric Edmonds, Carol Graham, and our discussants Ann Harrison and Branko Milanovic for helpful comments. This research was in part supported by funding from the National Science Foundation Grant SES \#0213459.
} 
between globalization and income inequality/poverty that we have more hope of pinning down empirically. Accordingly, we concentrate on recent trade liberalization episodes in developing countries (especially Latin America) that consisted primarily of drastic reductions in tariff barriers. As we argue below, such tariff reductions provide fairly accurate measures of the magnitude of trade liberalization in these countries. Moreover, for the countries under consideration, tariff reductions constitute a "big part" of the globalization process. Second, we focus mostly on the short- and medium-run effects of these episodes. These effects are easier to relate to trade policy changes compared to long-run, general equilibrium effects that spread over several years. From a policy perspective, concern about the negative short-run effects of trade liberalization often stands in the way of broad acceptance of free trade among the public and policy makers. Third, for identification reasons, we focus on the static link between trade policy and income distribution that operates through short- to medium-run changes in relative prices and wages, rather than the dynamic, indirect link from trade, to growth, to income inequality and poverty. This focus does not by any means reflect our belief that growth is not an important channel through which increased openness affects the income distribution. However, the literature on the relationship between trade and growth is already vast (see Winters et al (2004) for a recent review), and has failed to reach a consensus on the effect of trade on growth. Finally, as a matter of methodology, our survey focuses primarily on case studies of particular countries that have analyzed micro data from household or plant level surveys.

The remainder of this article is structured as follows. In section 2 we start by providing an overview of the relevant definitions and the conceptual issues associated with the measurement of trade liberalization, inequality, and poverty. In the same section we also review some of the commonly accepted facts regarding trends in inequality in developing countries. In section 3 we identify the main channels through which trade liberalization is presumed to have affected inequality in developing countries, and review the evidence on each of them. Section 4 focuses on poverty, and section 5 concludes.

\section{Trade Liberalization, Inequality, and Poverty: Definitions, Measurement Problems, and Some Common Ground}


(a) Trade Liberalization: Even if one confines the analysis to one particular aspect of globalization, trade liberalization, the measurement of trade liberalization is not without its problems. Trade protection has increasingly taken the form of non-tariff barriers (NTBs) that are inherently hard to measure. This use of NTBs is particularly pronounced in developed countries and presents a serious obstacle to any effort to measure the alleged increase in openness in the last three decades. The traditional approach to circumventing this challenge is to use imports, exports, or the sum of the two as proxies of a country's openness, and interpret their increase over time as the consequence of the fall of trade and/or transportation barriers. The obvious shortcoming with this method is that both imports and exports are determined simultaneously with the other variables that are the focus of the empirical analysis (e.g., wages, prices, etc.) so that interpretation of the results is subject to potentially serious simultaneity bias.

Against this background, trade liberalizations in many developing countries in the late 1980's and early 1990's represent a major advantage from a measurement point of view. Because many of these countries were either not GATT/WTO members (e.g., Mexico), or had not participated in the tariff-reducing GATT/WTO rounds prior to the reforms because of the exemption in article XVIII of GATT (e.g., Brazil, Colombia), they used tariffs as one of the primary policy tools. Tariffs are both easier to measure than NTBs and comparable across time. More importantly, although all countries also used NTBs, NTB coverage ratios (and their changes over time) are highly correlated with tariffs (and their changes). Hence, while tariff coefficients may overstate the pure tariff effect in regressions employing tariff changes as the right hand side variable, the coefficients nevertheless capture the combined effect of trade policy changes in each sector.

The use of tariffs provides two additional advantages. First, tariff changes vary substantially across industries during trade reform. Figure 1 plots sectoral tariff rates in 1998 against tariff rates in 1984 for Colombia, a country that experienced a drastic reduction in tariff rates between 1984 and 1994. It is apparent from this figure that trade liberalization did not simply reduce tariff rates, it also changed the structure of protection across industries. These differential tariff reductions across industries can be exploited to identify the effects of trade reform. Similar patterns of changing structure of protection are reported for Mexico for the 1984-1990 period (Hanson and Harrison (1999)), and Brazil for the 1987-1998 (Pavcnik, Blom, Goldberg, and Schady (2004)). While the unilateral trade liberalization "experiments” in these 
countries are less “clean” compared to Colombia, in the sense that they are accompanied by other substantial structural changes (deregulation, a substantial increase in FDI in Mexico, the effects of Mercosur in Brazil) ${ }^{1}$, the differential effects of tariff changes across industries enable one to separate the effects of trade liberalization from the effects of concurrent policy changes.

A second advantage is that the usual concern about the endogeneity of trade protection is less pronounced in countries that liberalized in response to becoming the GATT/WTO members (or in complying with the GATT/WTO negotiated rates). This reflects the government's objective to reduce tariffs across industries to more uniform rates negotiated with the WTO. Policymakers accordingly cater less to special lobby interests, so that tariff declines in each industry are proportional to the industry's pre-reform tariff levels (see, for example, Goldberg and Pavcnik (2004) for Colombia, and Pavcnik, Blom, Goldberg, and Schady (2004) for Brazil), alleviating concerns about endogeneity at least in the economic sense. This is evident in Figure 2 that plots the Colombian tariff declines between 1984 and 1998 for each sector against the pre-reform tariff levels in 1983. The relationship is strikingly linear with the most protected sectors in 1983 (e.g., textiles) experiencing the largest tariff declines. Of course, concern about the endogeneity of tariffs in the econometric sense still remains - that is, tariff changes could be correlated with unobserved sector-specific factors that also affected the dependent variables in the relevant regressions. However, the nature of the trade reforms suggests appropriate instruments. Because the total tariff changes in each sector are proportional to the pre-reform tariff levels, and the pace of the reforms (i.e. the year-to-year tariff change in each sector) was influenced by macroeconomic variables such as exchange rates, or the world prices of key agricultural commodities (e.g., the world price of coffee in Colombia), pre-reform tariff levels and their interactions with the world price of coffee, or exchange rates provide natural instruments for observed tariff changes.

While the measurement of trade liberalization through tariff changes and the availability of fairly powerful instruments due to the nature of trade reforms in Latin American countries represent improvements over previous attempts to pin down the effects of trade liberalization, it should also be recognized that the focus on tariff changes is informative only to the extent that tariff declines capture the essence of globalization in the corresponding countries. This is (arguably) the case in many Latin American countries were the tariff changes are significant,

\footnotetext{
${ }^{1}$ Even in Colombia, the trade reforms partially coincide chronologically with a major labor market reform.
} 
especially when one takes into account that they go hand in hand with substantial reductions in NTBs in the same sectors. In the textile and apparel sector in Colombia for example, tariff rates decline from $91 \%$ in 1984 to $18 \%$ in 1994, while the coverage ratio declines from 88 to less than $1 \%$. Given the magnitude of this policy change one would expect to see some response to trade reform in this sector and the Colombian economy in general. More recently, and in different developing countries, the extent to which tariff changes can capture the extent of globalization is rather limited. Tariffs are, for example, rather irrelevant in post-NAFTA Mexico, where capital flows, FDI, and immigration play a substantially more important role in the globalization process.

(b) Inequality: Measurement of inequality poses several challenges. As pointed out by Ravallion (2003) the definition of inequality is itself controversial. Most of the recent work on developing economies has focused on the relative version of inequality and found that trade reforms coincide chronologically with an increase in relative inequality ${ }^{2}$; this implies an even larger increase in absolute inequality. ${ }^{3}$

At the same time, many of the household surveys used to compute measures of inequality have come under scrutiny because of the suspected increase in the non-response rates of the richer households and because of inconsistencies in their design (see Ravallion (2003) and Deaton (2003) for a detailed discussion). With respect to the measurement of inequality in particular, what is of most concern is the counterintuitive result in Mistiaen and Ravallion (2003) and Deaton (2003) that when non-response rates are increasing with income, it is possible that the estimated variance of the truncated income distribution exceeds the variance of the true distribution (while the mean is lower), so that the usual measures of inequality based on the second moments of the observed income distribution can be completely uninformative about the true change in income inequality. Nevertheless, it seems unlikely that this drives the recent findings on increased inequality in many developing countries. One needs to assume very particular income distributions for the estimated variance to increase when the true variance decreases or remains constant. Moreover, most empirical work on inequality has used surveys

\footnotetext{
${ }^{2}$ See for example Behrman, Birdsall, and Szekely (2000), Sanchez-Paramo and Schady (2003), Robbins (1996), Hanson and Harrison (1999), Feliciano (2001), Robertson (2000), Attanasio, Goldberg and Pavcnik (2004), Pavcnik, Blom, Goldberg and Schady (2004).

${ }^{3}$ Consider two individuals. Relative inequality reflects the ratio of their incomes, while absolute inequality measures absolute difference in their incomes.
} 
from adjacent years, documenting an increase in inequality occurring within a short period of time, often 3-5 years. While non-response among high-income households is clearly an issue, especially in surveys from Latin America (see Szekely and Hilgert (1999)), for the results on inequality to be misleading it would have to be the case that not only high income households do not respond, but also that the non-response rate increased dramatically within a short period of 35 years. This seems unlikely in practice.

What is perhaps more disconcerting is the fact that the design of the surveys from developing countries often changes from year to year, making comparisons across years difficult. ${ }^{4}$ Despite these difficulties, the widely documented increase in inequality for several countries is likely not just an artifact of faulty survey design and inconsistencies across years. The finding of increased inequality is based typically on comparisons of the wages between skilled and unskilled workers rather than on the second moments of the income distribution ${ }^{5}$. While one can certainly think of cases where changes in the survey design would give the appearance of an increase in the skill premium, it seems unlikely that such cases account for the documented increase in the skill premium for several countries. In addition, the observed increases in skill premium over a short period of time are relatively large in magnitude, which casts doubt that the increases are driven by survey design and non-reporting issues alone. In Mexico, for example, Cragg and Epelbaum (1996) document a skill premium increase of about 68\% between 1987 and 1993. For other countries, such as Colombia or Brazil, the increase is less pronounced, but nevertheless significant; for Colombia, in particular, Attanasio, Goldberg and Pavcnik (2004) report a 20\% increase between 1990 and 1998. Hence, while the exact numbers reported in existing studies of inequality may not be completely accurate, the widely documented trends in wage inequality are unlikely simply a figment of data problems. That said, we need to emphasize that these studies inform us only about wage inequality, and not the broader concept of income inequality - not to mention consumption inequality.

Given the magnitude of the skill premium increase, a large number of studies have focused on potential explanations. Despite their differences, all these explanations agree that the increase in the skill premium is driven by increased demand for skilled workers. The relevant

\footnotetext{
${ }^{4}$ One such example of a design change is the case of Colombia, where the topcoding procedures used in the Encuesta Nacional de Hogares (the National Household Survey) changed in the early 1990's affecting the reporting of the income of the richer households.

${ }^{5}$ Studies that use labor force surveys define skill based on the level of education. Studies that use firm-level data usually differentiate between white-collar and blue-collar workers (or non-production and production workers).
} 
arguments can be found in Robbins (1996) and Sanchez-Paramo and Schady (2003), and are similar to the ones used in the context of the developed world. These arguments are reinforced by the fact that Latin American countries did not experience the same increase in the supply of educated workers as the U.S. or East-Asian economies (Attanasio and Szekely (2000), SanchezParamo and Schady (2003)).

The next section reviews the main explanations for why demand for skilled workers may have increased in developing countries, discussing in each case the connection to trade liberalization. The most prominent explanations include: (a) increase in the returns to particular occupations that are associated with a higher educational level; (b) general equilibrium effects consistent with the Heckscher-Ohlin model of international trade; (c) shift of skill-intensive intermediate goods production from developed to developing countries; a more general version of the above hypothesis would include the increase of FDI flows towards developing countries emphasizing the complementarity between capital and skilled-labor; (d) skill-biased technological change; and (e) compositional changes in the products produced by developing countries within industries, with the mix shifting towards more skilled-labor intensive products.

While most work has focused on potential explanations for the increasing inequality between skilled and unskilled workers, the skill premium alone cannot fully explain the increase in inequality in developing countries. In Colombia, for example, Attanasio, Goldberg, and Pavcnik (2004) compute separate measures of inequality for workers in 3 education groups. They demonstrate that inequality has increased within each of the three groups, with the most pronounced increase for the university-educated group. Moreover, earnings regressions relating wages to various demographics and job characteristics show that the increase in the returns to education can explain only a small fraction of the variance of log wages. This suggests that factors other than skill premium contributed to wage inequality. In the remainder of section 3 we focus on two such factors. The first one is a trade-policy-induced-change in industry wage premiums that have disproportionately affected workers at the left tail of the wage distribution. The second one is the alleged increase in the size of the informal sector that is presumed to offer worse working conditions and lower wages.

Finally, at the end of section 3 we briefly discuss a small set of recent theoretical studies that have offered alternative explanations for the increasing inequality in developing countries. 
Since our focus is mostly empirical, we discuss these theories only briefly, as empirical support for them is still pending.

(c) Poverty: While the literature on trade and inequality is voluminous, there is virtually no work to date on the relationship between trade liberalization and poverty. Yet, the effect of free trade on poverty fairs prominently in the mind of the public. Increased inequality seems more acceptable if it is accompanied by fast growth so that - despite rising disparities - the poor do better in an absolute sense.

As has been repeatedly pointed out by Deaton (2003) and Ravallion (2003), an operational definition of poverty raises itself important philosophical and measurement issues. We do not review these issues here since they have been extensively explored in the work of the aforementioned authors. When we use the term "poverty" in the remainder of this article we do so with the concept of "absolute” poverty in mind. This is not based on our belief that an absolute criterion for the measurement of poverty is conceptually the "right" yardstick. But given that a relative measure of poverty is by nature similar to a measure of inequality, most of the issues related to trade and "relative" poverty would be covered already in the section on inequality.

Identifying the relationship between poverty and trade liberalization poses a tremendous challenge. To begin with, poverty has proven hard to measure - even harder than inequality. This is not surprising given that - when an absolute poverty line is used - poverty measurement requires getting the per capita income or consumption figures exactly right, or at a minimum measuring them consistently over time. This is a difficult task. Consequently, even though most agree that worldwide poverty has declined, there is little consensus to date about the magnitude of the decline.

Moreover, the most important channel through which poverty is likely to be affected is through growth. As discussed above, the relationship between trade and growth has itself been empirically elusive leaving little hope that one can establish a further link to poverty. Finally, most of the world's poor are found in rural areas (see World Bank (2000), p. 280). In Colombia for example, World Bank sources estimate (using the (liberal) \$2 per day absolute poverty line) that in 1988 13\% of urban residents lived in poverty, while the corresponding percentage for rural areas was 50\%. By 1999 these numbers had evolved to 12\% and 42\% respectively (World 
Bank (2002), p. 12). This concentration of poverty in rural areas is destined to frustrate any efforts to empirically link operational measures of trade liberalization to poverty for two main reasons.

First, on the data side, most household surveys (at least in Latin America) predominately cover urban households, making any assessment of the effect of trade policy on the rural poverty difficult. ${ }^{6}$ More importantly, the recent trade liberalization episodes in developing countries that have been exploited in the context of the inequality debate were concentrated on the manufacturing sector, which tends to be located around urban areas. For example, in Colombia, average tariffs in manufacturing dropped from 50 to 13 percent between 1984 and 1998 (with sectors such as textile and apparel experiencing over 70 percentage point tariff decline). During the same period, average tariffs in agriculture declined by less then 14 percentage points from 25 to 10.7 percent. Accordingly, it is hard to establish any direct link between tariff- or NTBreductions and poverty measures in rural areas, at least in the short or medium run. To the extent that trade liberalization did affect the rural poor, this link is likely indirect, through immigration and increased employment opportunities in growing sectors. But then we are back to the growth debate.

A further difficulty is that existing research predominately focuses on the impact of unilateral trade liberalization in developing countries. However, various policies in developed countries, such as export and production subsidies, import tariffs, and quotas that shelter agricultural and food products in the developed world from foreign competition potentially also have important implications for poverty in developing countries, especially in rural areas. World Bank (2000), for example, views the removal of these protectionist measures as an important tool in combating global poverty, and simulations based on computable general equilibrium models suggest large welfare gains stemming from the removal of such barriers (Anderson (2003)). Yet, we are not aware of any empirical studies that analyze the implications of these policies for the well-being of the rural poor in developing countries by linking intertemporal variation in trade policy measures to household surveys that span trade liberalization episodes.

Given the above difficulties, a perhaps more promising approach is to focus on particular phenomena that are presumably highly correlated with poverty, and try to establish a link

\footnotetext{
${ }^{6}$ When rural surveys exist (for example in Colombia), they often contain less detail on labor market activities. For example, in Colombia, nationwide surveys do not include the module on informality.
} 
between trade liberalization and the incidence of such phenomena. In section 4, we specifically focus on labor market and consumption effects that may fall disproportionately on the poor, and review evidence of how trade liberalization may have affected unemployment; wages of unskilled workers, employment in the informal sector; compliance with minimum wage legislation; child labor; and relative prices of consumer goods. This approach does not relate trade to poverty measures directly. Furthermore, it admittedly says little about what we believe is the most important channel through which poverty is likely to be affected, namely growth. But consistent with the spirit of the section on inequality, we place emphasis on those aspects of the relationship between trade and poverty that we have some hope of capturing empirically. In the same section, we also review the only empirical study (Porto 2004a) that has to our knowledge provided a general equilibrium analysis of the relationship between trade liberalization and poverty, by simultaneously considering the labor market and consumption effects of trade liberalization. Section 5 concludes.

\section{Trade Liberalization and Inequality}

\subsection{Explanations for the Increase of the Skill Premium}

\section{(1) Changes in the Returns to Skill-Intensive Occupations}

A possible explanation for the increase in the skill premium documented in many developing countries is that the returns to particular occupations that require a higher level of education have increased. Cragg and Epelbaum (1996) find strong support for this hypothesis in the case of preNAFTA Mexico. In particular, these authors document a rapid increase in the occupational premia of professionals and administrators (including public administrators). More importantly, these changing premia to skill-intensive occupations account for a significant fraction of the estimated skill premium increase: controlling for occupation compresses the original estimate of the change in the premium of post-secondary to secondary education from 67 to $40 \%$. Similarly, the increase in the premium of post-secondary to primary education drops from $70 \%$ to $42 \%$ once occupation is controlled for.

The authors attribute the increase in these occupational premia to the rapid changes introduced in the economy by reforms that increased the demand for individuals who could enact 
these reforms: managers and professionals. The link to the trade reform is indirect: trade reforms impacted these changing returns to occupation only to the extent that they were part of the general reforms that generated demand for highly educated individuals.

Studies on other countries have however found less support for rapidly changing returns to skill-intensive occupations. In Colombia, Attanasio, Goldberg, and Pavcnik (2004) document that occupational returns remained relatively stable over the 1986-1998 period. And while, consistent with Cragg and Epelbaum's story there is a spike in the returns to "managers and other professionals” in 1992, a year following dramatic trade and labor reform, this spike is short-lived and cannot explain the increase in the skill premium in the late 1980's and 1990's. Hence, other factors must drive the increase in the skill premium in this case.

\section{(2) Stolper-Samuelson Effects}

The idea that trade liberalization could be the cause of the rising skill premium documented in many developing countries is often dismissed on the grounds that the most widely used model of international trade, the Heckscher-Ohlin model, would imply exactly the opposite, namely a decrease in the wage gap between skilled and unskilled workers.

The usual premise is that developed countries are relatively abundant in skilled labor, while developing countries are relatively abundant in unskilled labor. Hence, according to a simple 2x2 version of the Heckscher-Ohlin model, developing countries will specialize in the production of unskilled-labor-intensive products (for example textiles and footwear), while developed countries will specialize in skilled-labor intensive products (for example machinery). A direct implication of this simple version of the model is also that developing countries will import skilled-labor intensive products, and - to the extent that they use any trade barriers these trade barriers will be imposed on the skilled-labor-intensive import sector. Trade-reforminduced declines in protection will thus lower the relative price of the skilled-labor intensive imported good. According to the Stolper-Samuelson theorem that links product prices to wages in a Hecksher-Ohlin model, the price decrease in the import sector will reduce the wages of skilled workers (used intensively in the import-competing sector) and benefit the unskilled 
workers (used intensively in the export sector). ${ }^{7}$ Because the model assumes that the factors of production can move across sectors within a country, the price changes affect only the economywide returns to factors of production. Thus, trade liberalization should be associated with reductions in poverty and inequality in developing world. The increase in the skill premium and inequality in many developing countries in the aftermath of trade liberalization thus at first glance contradicts the prediction of the Stolper-Samuelson theorem.

However, this increase in the skill premium in many developing countries (and in Latin America in particular) is consistent with the Stolper-Samuelson theorem because unskilled-labor intensive sectors were protected with the highest tariffs prior to trade reform and experienced the largest tariff reductions during trade reform. These protection patterns have been reported for Colombia (Attanasio, Goldberg, Pavcnik (2004)), Mexico (Hanson and Harrison (1999), Robertson (2000, 2004 for pre-NAFTA period), Morocco (Currie and Harrison (1997)), and Brazil (Pavcnik, Blom, Goldberg and Schady (2004)). Given this evidence, the increase in the skill premium is exactly what Stolper-Samuelson would predict: since trade liberalization was concentrated in unskilled-labor-intensive sectors, the economy-wide return to unskilled labor should decrease. This argument demonstrates the advantages of exploiting the sectoral variation in tariff changes, as opposed to relying on time variation alone to identify the effects of trade policy changes. Studies that simply use "before-after-comparisons" to uncover the effects of trade liberalization miss the important fact that - unlike in textbooks of International Trade - the comparison is not between autarky and free trade, but rather between protection and "lessprotection”, so that the pattern of protection across sectors prior to liberalization is crucial in determining the effects of trade reforms.

The above evidence alone, however, is not sufficient to conclude that the increase in the skill premium was driven by trade reforms via the Hecksher-Ohlin mechanism. In fact, other pieces of evidence cast doubt on this explanation. First, the Hecksher-Ohlin model implies that industries that experience a tariff-induced decline (increase) in their relative price would contract (expand). Consequently, labor should reallocate from the sectors with the largest tariff cuts to the sectors with the smaller tariff cuts. Yet, a common finding of studies of trade liberalization in developing countries is the lack of such reallocation. For example, in Colombia, a regression of

\footnotetext{
${ }^{7}$ These sharp predictions of the simple 2x2 version of the model are not necessarily preserved in higher-dimensional versions of the model
} 
industry employment shares on industry tariffs, industry, and time indicators yields the tariff coefficient that is small in magnitude and statistically insignificant (Attanasio, Goldberg, and Pavcnik (2004). The lack of labor reallocation following trade reform has also been observed in several other developing countries (specifically, by Revenga (1997), Hanson and Harrison (1999), and Feliciano (2001) for Mexico; by Currie and Harrison (1997) for Morocco; and by Wacziarg and Seddon (2004) in a cross-country study of trade liberalization, where, however, trade liberalization is captured only through a time dummy). These studies attribute the lack of labor reallocation in response to trade reform to either rigid labor markets (so that the adjustment to trade liberalization occurs through relative wage adjustments (Colombia, Mexico)), or to the existence of imperfect product markets (so that firms respond by lowering of profit margins (Mexico, Morocco) and not through labor reallocation across sectors). In sharp contrast, Grossman (1986) and Revenga (1992) find greater employment than wage sensitivity to trade shocks for the U.S. These differences in the adjustment mechanisms are consistent with greater labor mobility in the United States compared to the developing economies.

A second piece of evidence that seems inconsistent with Stolper-Samuelson effects is that empirical work on developing countries typically finds that the share of skilled workers has increased substantially within most industries in the last two decades. Within-industry increases in the share of skilled workers have been reported for Argentina, Brazil, Mexico, Chile, and Colombia (Robbins (1996), Sanchez-Paramo and Schady (2003), Attanasio, Goldberg, Pavcnik (2004)). Stolper-Samuelson effects would in contrast suggest that firms should substitute away from skilled labor given the higher relative price of skilled workers (rising skill premium). The higher share of skilled workers in most industries points to skilled-biased technological change, an explanation that has received a lot of attention in the context of the rising inequality in developed countries. ${ }^{8}$

Even though the aforementioned stylized facts seem more consistent with skill-biased technological change than Stolper-Samuelson effects following trade reforms, trade liberalization could still have contributed to the rise in the skill premium if technological change had itself been an endogenous response to more “openness”. We investigate this possibility later in this section.

\footnotetext{
${ }^{8}$ Leamer (1998) argues that sector-bias and not factor-bias determines changes in the wage distribution. This argument however requires that product prices do not change, which is unlikely the case during a trade reform. Moreover, there has been no empirical support for this theory (see Attanasio, Goldberg, and Pavcnik (2004)).
} 


\section{(3) Relocation of Intermediate-Goods Production or "Global Production Sharing", FDI, and Complementarity between Capital and Labor}

The discussion of the general equilibrium mechanism linking trade policy to changes in relative wages has so far implicitly assumed (as is typically done in this literature) that all trade occurs in final goods. This premise is seriously questioned in Feenstra and Hanson $(1996,2003)$ who point to the importance of trade in intermediate goods, and argue that the increase in "global production sharing” or outsourcing can in part account for the increased demand for skilled workers in both the developed and developing countries.

The basic argument in Feenstra and Hanson rests on the assumption that production of final goods requires the use of intermediate inputs that differ in their skill intensities. Trade liberalization and/or removal of capital controls shift the production of some of these intermediate goods from developed to developing countries. While such products would be characterized as unskilled-labor-intensive from a developed country's perspective, they appear skilled-labor-intensive when considered from the developing country's point of view. As a result, the average skill intensity increases in both the developed and developing economies, inducing an increase in the skill premium in both places.

A more general version of the above argument emphasizes the role of foreign direct investment (not necessarily linked to the production of intermediate products) in generating additional demand for skilled workers in developing countries. If capital and skilled labor are complements, lower prices of capital goods induced by trade liberalization will increase demand not only for capital goods but also for skilled labor (Cragg and Epelbaum (1996), Behrman, Birdsall, and Szekely (2000)).

Empirical work has found strong support for the "global production sharing" hypothesis for Mexico, where many U.S. firms export intermediate inputs to maquiladora plants, in which the assembly of inputs and other production activities occur (see Feenstra and Hanson (1997)). However, we are not aware of any other studies linking the increase in inequality observed in developing countries to outsourcing. This is partly due to the fact that most empirical work has focused on the role of outsourcing in the developed rather than developing countries. But it could also reflect the fact there are few developing countries that have received as large FDI 
flows as Mexico (outsourcing of Hong-Kong production activities to China is another example). The size of FDI flows to Mexico could be due to Mexico's substantial investment liberalization in addition to the reduction of tariff and NTBs during the 1980s, and to its proximity to the United States.

\section{(4) Skill-Biased Technological Change}

The evidence in favor of skilled-biased technological change does not necessarily imply that trade policy did not indirectly contribute to changes in the wage distribution. Of course, it is possible that there has been worldwide skill-biased technological change, independent of trade opening, so that inequality would increase in the absence of trade reform. If, however, technological change was itself an endogenous response to more "openness", one could argue that the trade reforms were indirectly responsible for the increase in the skill premium.

Several recent theoretical papers have explored channels through which trade openness may have induced or at least contributed to skill-biased technological change. The earliest of them include Wood's (1995) hypothesis of “defensive innovation”, according to which intensified competition from abroad may induce firms to engage in R\&D, or at a minimum, take advantage of existing new technologies that they may have had little incentive to adopt prior to liberalization. This argument is developed further in Thoenig and Verdier (2003). While this hypothesis seems more suitable to explaining the increase in inequality in the developed world, it may also be applicable to middle-income developing countries, such as Colombia or Brazil, if they face import competition in their low-skill-intensive sectors from low-income developing countries (e.g., China), so that they find it necessary to protect these sectors. On the empirical side, a common implication of these models is that in the short- and medium-run, skill-biased technological change should be more pronounced in the sectors that liberalized more.

A somewhat different mechanism through which trade liberalization can induce (or accelerate) skill-biased technological change is put forward in Acemoglu (2003) who develops a model of endogenous technological change, and argues that in the case of developing countries this technological change may take the form of increased imports of machines, office equipment, and other capital goods that are complementary to skilled labor. Trade liberalization affects the demand for skilled workers by reducing the prices of the relevant capital goods and hence 
increasing their imports. From an empirical point of view, this model has two distinct implications: first, following a trade liberalization episode in a developing country, total imports for office equipment and advanced machinery from developed countries should increase; and second, the increase in the demand for skilled workers should be more pronounced in sectors that import more foreign machinery.

Yet another mechanism through which trade liberalization can affect technological change and thus indirectly inequality is suggested by Aghion, Burgess, Redding and Zilibotti (2003). In their model firms' response to trade liberalization depends on how close they are to the technology frontier. Firms that are sufficiently close to the frontier can survive or deter entry of (foreign) competitors by innovating; firms that are far from the frontier may not be able to fight external entry. Hence, the average effect of trade liberalization will depend on the fraction of firms and sectors that are sufficiently close to the frontier to fight for their survival. In addition, Aghion, Burgess, Redding, and Zilibotti emphasize the role of domestic institutions, labor market restrictions in particular, and their interactions with technology adoption for the distributional effects of trade policy.

Finally, a different line of explanation focuses on the increased exports from developing countries following trade reforms. Empirical evidence from the United States suggests that exporting is a skill-intensive activity (see Bernard and Jensen (1997)); to the extent that this is also true for the developing countries, an increase in exports will increase the relative demand for skilled labor. In fact, empirical evidence from Mexico by Harrison and Hanson (1999) finds a positive association between a firm's exporting status and the relative employment of whitecollar workers during a period of trade liberalization.

While empirical work on the effects of trade alone, or skilled-biased technological change alone on inequality has been abundant, empirical studies of the interactions of these two mechanisms are scant. Attanasio, Goldberg, and Pavcnik (2004) find some support for the Wood / Thoenig and Verdier theory for Colombia. In particular, regressions relating the change in the share of skilled workers in each sector to the change in tariff protection over the 1984-1998 period show that the increase in demand for skilled workers was largest in those sectors that experienced the largest tariff cuts (e.g., textiles and apparel). This provides some support for the theory that skilled-biased technological change was itself an endogenous response to trade liberalization. Lack of data on machinery or office equipment purchases prevent the authors from 
exploring the channel emphasized in Acemoglu's work. However, related work suggests that this channel might play a role in some countries. For the period surrounding the 1980's Mexican trade liberalization episode, Harrison and Hanson (1999) find that, within each Mexican industry, firms that import machinery and materials are more likely to employ a higher share of white-collar workers than firms that do not import these inputs. Pavcnik (2003), on the other hand, finds that the increased relative plant demand for white-collar workers by Chilean plants in early 1980's cannot be attributed to the use of imported materials and foreign technical assistance by these plants, once one controls for time-invariant plant characteristics.

In the empirical part of their paper, Aghion, Burgess, Redding and Zilibotti (2003) look at the Indian trade liberalization of 1991 for support of their theory. Consistent with their theoretical arguments, productivity and profits increased by more in 3-digit industries that were close to the Indian productivity frontier and in states that had more flexible labor market institutions. ${ }^{9}$ This differential impact of trade liberalization across industries with different proximity to the technology frontier and states with different regulatory regimes had strong inequalizing effects.

To our knowledge, no other work has attempted to relate skilled-biased technological change, as measured by the increase in the share of skilled workers by sector, to trade liberalization in developing world. Clearly, more evidence from other developing countries is needed before one can draw general conclusions. Along the same lines, no empirical studies have linked skilled-biased technological change in developing countries to the rise in aggregate exports. However, some recent work has focused on the changing composition of exports as a driving force of inequality. We refer to this work in more detail in the next subsection.

\section{(5) Compositional Changes: “Quality” upgrading of firms and/or products}

As discussed above, a common and puzzling finding of studies of trade liberalization in developing countries is the lack of labor reallocation across sectors. This lack of movement is in stark contrast with the results of studies of the effects of trade reform on productivity that exploit plant- or firm-level data. The latter studies document major resource reallocations across firms

\footnotetext{
${ }^{9}$ However, using firm-level data and detailed information on industry tariffs from India, Topalova (2004) concludes that tariff declines are associated with productivity improvements in firms with high and low productivity prior to the trade reform.
} 
in the aftermath of liberalization with resources typically flowing from less-productive to moreproductive firms (often within the same industry), so that aggregate industry productivity increases. One possibility to reconcile these seemingly conflicting findings on factor mobility is that there is a lot of labor movement across firms, often within the same industry, that are not visible at the aggregation level at which industry of employment is reported in household surveys.

Recent work has increasingly focused on compositional changes in response to trade liberalization that may induce reallocation of both capital and labor towards "higher quality" firms. The basic idea is that trade openness induces a "quality" upgrading of firms, where quality can mean either "firm productivity" or "product quality". No matter what interpretation one adopts, what is essential for establishing a connection with the inequality debate is that these "higher quality" firms employ a higher proportion of skilled workers, so that aggregate demand for skilled workers increases relative to that for unskilled workers. The quality upgrading in response to trade openness can itself arise either because firms in import competing sectors try to avoid competition from cheaper countries by differentiating themselves, or because trade can shift resources from non-exporters to exporters (see Melitz (2003) for a related argument), and there is ample empirical evidence that exporters tend to be more "productive" than nonexporters.

Despite the theoretical appeal and plausibility of these arguments that emphasize firm and plant heterogeneity, the empirical evidence on how this channel affects inequality is still scant and mostly indirect. Schott (2004) provides strong evidence of complete specialization by countries within product categories, with the skill- and capital-abundant countries specializing in the production and export of higher unit value products, and unskilled-labor-abundant countries specializing in the production and export of low-unit value products. If one accepts the plausible premise that unit values within very narrowly defined product categories (based on 7-digit Tariff Schedule code and 10-digit Harmonized System code), reflect differences in product "quality", then the implication of Schott's findings is that developed countries specialize in higher quality products while developing countries specialize in lower quality products within the same product category. While these findings do not tell us directly how countries adjust to trade liberalization, it seems plausible to assume that as developing countries become more open to trade, they engage in more product differentiation along the same lines as more developed countries. 
More direct evidence on this mechanism is provided in a recent paper by Verhoogen (2004). Rather than focusing on trade liberalization, Verhoogen exploits a major exchange rate depreciation episode (the 1994 peso crisis in Mexico) to study the response of firms to increased openness. The peso depreciation clearly benefited exporters. Instead of focusing on the effects of an increase in aggregate exports on productivity or demand for skilled workers (see related discussion in previous section), Verhoogen considers the effects of the exchange rate depreciation on firms of different “quality”. Quality is defined as “product quality”. The basic hypothesis is that the increase in exports was associated with an increase in the quality of the products produced by exporting firms. But higher quality products require a higher proportion of skilled workers. Hence the relative demand for skilled workers increased, widening the wage gap between skilled and unskilled. Moreover, Verhoogen finds that high and low quality firms experienced similar wage inequality growth patterns during time periods without large exchange rate shocks. This robustness analysis confirms that the main findings do not simply reflect preexisting time trends in wage inequality growth that varied across the two types of firms (potentially due to differences in unobserved characteristics), but they were truly the result of firms’ differential responses to the exchange rate shock.

The main challenge of this literature is to define "quality" in an operational way. As Erdem and Tybout (2004) have pointed out, a separation of "firm productivity" and what we typically mean by "product quality” is not possible given the available data sets. Moreover, the term "quality" is itself elusive from an empirical point of view, especially in the context of a horizontal differentiation model, in which consumers value products differently. Schott (2004) tries to circumvent this problem by using unit-value data and assuming that higher unit-values reflect higher quality. Verhoogen (2004) assumes that higher quantity (a plant's total sales) can proxy for higher "product quality”, a clearly controversial assumption. Fortunately, from the perspective of the inequality debate, it does not matter what definition of "quality" one adopts. What matters is the proportion of skilled and unskilled workers that is required to produce goods before and after a trade liberalization, or currency depreciation episode. If the proportion of skilled workers increases within firms, this is going to induce an increase in the skill premium. Hence, rather than resorting to particular interpretations of product "quality” that may be controversial, empirical work in this area could directly examine how within-firm relative demand for skilled workers is affected by trade liberalization, and whether this effect is different 
for firms with initially low versus high skill-intensity (where "initial” refers to the skill-intensity observed prior to the trade reform or exchange rate depreciation episode).

The second challenge facing this literature is of course that for the results to be relevant for the inequality debate, it is important to have accurate measures of skill. Unfortunately, the information on worker and job characteristics provided in firm level data sets is much more limited that what is usually provided in household surveys, so that researchers have to resort to the familiar dichotomy between production and non-production workers. While in the absence of more detailed information, there is little one can do in the short run, in the longer run more information about the characteristics of workers employed by different firms (or plants) will be essential for establishing a connection between firm heterogeneity and changes in the wage distribution.

\subsection{Changes in Industry Wage Premiums}

As discussed in section 2, empirical evidence suggests that the increase in the economywide skill-premium alone (regardless of the underlying causes) cannot fully explain the growing wage inequality. In this section, we consider industry wage premiums as an alternative channel through which trade liberalization may have contributed to wage inequality.

Industry wage premiums refer to the part of worker wages that cannot be explained by observable worker characteristics such as gender, age, education, experience, etc., but can be attributed to workers’ industry affiliation. Many studies have found that industry wage premiums account for a significant portion of individual wage variation; however, there is less agreement as to whether these premiums reflect compensating differentials, efficiency wages, industry rents, or returns to industry-specific skills.

Trade theory suggests several plausible channels through which trade policy changes may affect industry wage premiums. First, in short- and medium-run models of trade where workers cannot easily move across sectors, tariff cuts translate into proportional declines in industry wage premiums. This channel may be particularly important in developing countries, where labor mobility in the aftermath of a trade shock may be obstructed by labor market rigidities (Heckman and Pages (2000)). In principle, these labor market rigidities might not be important in practice because of vast non-compliance with labor market regulation. However, the lack of labor 
reallocation across sectors in the aftermath of dramatic tariff declines in several countries discussed in section 3 is consistent with the idea of rigid labor markets. In addition, these studies find that the observed changes in the industry shares in total employment are not correlated with tariff changes. Thus, the idea that the industries affected by trade reforms may adjust via the wage, rather than the employment channel, deserves some consideration.

Second, while the traditional short- and medium- run models of trade assume perfect competition, trade policy may also affect industry wage premiums in settings with imperfect competition in product and labor markets. For example, profitable industries may share part of their rents with workers because of union bargaining power. If tariff cuts are associated with lower markups, industry wage premiums could decline via lower industry rents. In fact, Harrison (1994), Levinsohn (1993), and Currie and Harrison (1997) find that firms’ markups decline in response to trade liberalization for Cote d'Ivoire, Turkey, and Morocco, respectively. Moreover, industry wage premiums may be affected by trade policy in models where unions share in industry rents through employment security guarantees rather than wages, and where employment security is obtained through higher trade protection (Grossman (1984)).

Finally, trade policy could affect industry wage premiums via industry-level productivity changes. While theory suggests that trade liberalization could either increase or decrease productivity, recent empirical studies suggest that trade liberalization is associated with productivity improvements in developing countries (Harrison (1994) for Cote d'Ivoire, Krishna and Mitra (1998), Aghion, Burgess, Redding, Zilibotti (2003), and Topalova (2003) for India, Kim (2000) for Korea, Pavcnik for Chile (2002), Fernandes for Colombia (2003), Muendler (2004) and Hay (2001) for Brazil). If these productivity gains are shared with workers in the form of higher wages, trade liberalization could increase industry wage premiums in sectors that experienced largest tariff cuts.

Regardless of the exact source of industry wage premium changes, trade-liberalization induced changes in industry wage premiums could contribute to increases in the wage inequality between skilled and unskilled workers through two channels.

First, if trade liberalization leads to declines in industry wage premiums, wage inequality between skilled and unskilled workers could increase if the industries with the largest tariff cuts are the ones employing a higher share of unskilled workers and if these industries had the lowest wage premiums prior to the reform. Evidence on how responsive industry wage premiums are to 
trade reforms is mixed. Some studies find no association between tariffs and industry wage premiums (Feliciano (2001) for Mexico, Pavcnik, Blom, Goldberg, and Schady (2004) for Brazil), while others find a positive association between tariff declines and industry wage premiums (Goldberg and Pavcnik (2004) for Colombia). ${ }^{10}$ Feliciano (2001) reports a positive association between declines in import licenses and industry wage premiums. Thus, in Colombia and Mexico, trade liberalization could in principle lead to increased wage inequality through the industry wage premium channel, especially since tariff cuts in these countries were the largest in unskilled-labor intensive industries (see section 3 for details) and the sectors with the largest tariff cuts had the lowest wage premiums prior to the reform (Attanasio, Goldberg, and Pavcnik (2004)). However, the magnitudes of the effects are relatively small, especially when compared to relatively large increases in wage inequality. For example, in Colombia, the estimates suggest that the average tariff reduction in manufacturing sector of 37 percentage points would be associated with $4 \%$ decline in industry wage premium. Moreover, in Colombia, industry wage premiums account for about $2 \%$ of explained variation in log hourly wages conditional on workers' observable characteristics. Thus, while changes in industry wages contribute to the increase in wage inequality between skilled and unskilled workers, other sources likely play a more important role.

Second, industry-wage premium changes could also contribute to the growing wage inequality between skilled and unskilled workers if they vary across workers with different skill levels, and if trade liberalization is associated with increases in industry-specific skill premiums. Sector-specific skill premiums could, for example, arise if workers with different skills differ in their intersectoral mobility, accumulation of sector-specific human capital, or bargaining power. However, the existing empirical evidence finds little support for this channel. In Brazil, Pavcnik, Blom, Goldberg, and Schady (2004) find that skill premiums vary widely across sectors. ${ }^{11}$ Attanasio, Goldberg, and Pavcnik (2004) find this to a lesser extent for Colombia. Yet, in both cases, changes in sector-specific skill premiums are not correlated with sector-specific tariff reductions.

\footnotetext{
${ }^{10}$ Studies that rely on average firm or industry wages rather than industry wage premiums also report mixed results: no association between changes in industry wages and tariffs in Morocco (Currie and Harrison (1997) and positive association in Mexico (Revenga (1997)).

${ }^{11}$ For example, the standard deviation of industry wage premiums ranges between 10 to 20 percent in various years.
} 
In sum, evidence from Colombia and Mexico suggests that trade-induced declines in wage premiums contributed to the growing wage inequality between skilled and unskilled workers in these countries. However, the responsiveness of industry wage premiums to tariff cuts differs across countries, and it is generally estimated to be small. One potential explanation for the relatively small magnitude of industry wage responses and the lack of labor reallocation across sectors is the existence of the informal sector. This sector offers an additional margin through which firms can adjust to trade shocks. We explore how trade liberalization affects the informal sector and the potential importance of the informal sector in explaining trade-induced wage inequality next.

\subsection{Changes in the size of the informal sector}

Trade liberalization could also increase wage inequality by expanding the size of the informal sector. The informal sector is usually defined as the sector of the economy that does not comply with labor market regulation such as minimum wage laws, hiring/firing regulations, or minimum age laws, and does not provide worker benefits. A broader definition of the informal sector may also include temporary workers in formal establishments. In many developing countries, the informal sector actually accounts for a large share of the labor force. For example, in urban Colombia, 50 to $60 \%$ of the labor force is employed in the informal sector. ${ }^{12}$

Opponents of globalization often claim that globalization might increase wage inequality by reducing firms' compliance with labor standards and increasing the informal sector of the economy. In particular, their argument suggest that firms that are exposed to foreign competition and need to cut costs may do so by not complying with labor market regulation or by replacing permanent workers with temporary ones. Alternatively, these firms may circumvent labor market regulation by outsourcing their activities to smaller, informal firms. Or, firms in the formal sector may lay-off workers, who in turn obtain informal jobs. From a theoretical standpoint, one potential problem with such arguments is the question of why profit maximizing firms had not cut costs by switching toward informal workers prior to the reforms. Goldberg and Pavcnik (2003) present a model that formalizes the above arguments of globalization opponents

\footnotetext{
${ }^{12}$ In the Colombian labor market survey, a worker is considered to work in the informal sector if his/her employer does not contribute to the social security fund as required by the law.
} 
and shows that permanent trade liberalization can indeed lead to an increase in the informal sector. $^{13}$

If trade liberalization increases the probability of working in the informal sector, and if the informal sector is associated with lower wages and worse job quality, trade liberalization could in principle contribute to increased inequality, where inequality is broadly defined as the gap between individuals that hold jobs with good working conditions, benefits, higher wages and those that do not.

Very little empirical work has examined the relationship between trade liberalization and the informal employment. This partially reflects the scarcity of labor force surveys that contain sufficient information to distinguish between formal and informal workers. Moreover, the existing results should be interpreted with several caveats. First, while the definition of the informal sector in various studies captures the broad idea of non-compliance with the labor market regulation, the exact source of non-compliance may differ across countries. ${ }^{14}$ One should thus be cautious about comparison of results across studies from different countries. Second, the surveyed empirical work in general focuses on non-compliance with economic labor standards such as social security benefits, severance payments, and minimum wage laws and not compliance with core labor standards such as forced and compulsory labor laws and child labor laws. Finally, the empirical work is based on household surveys and will miss individuals that do not live within households that are in the sampling frame. Particularly vulnerable groups include bonded laborers and street children who are likely missing from the data.

Before we review the evidence on the relationship between trade liberalization and the size of the informal sector, let us first address the controversial issue of whether the informal sector is indeed associated with lower wages and lower job quality. Several studies conclude that workers with the same observable characteristics earn less in the informal than formal sector in Peru and El Salvador (Marcouiller, Ruiz de Castilla, and Woodruff (1997)), Brazil (table 3, Pavcnik, Blom, Goldberg, and Schady (2004)) and Colombia (table 3, Attanasio, Goldberg, and Pavcnik (2004)). For example, in Colombia, a worker in the informal sector earns between 1.7 to

\footnotetext{
${ }^{13}$ One can also think of models which yield the opposite predictions. The main point of the model is to show that the view held by many globalization opponents can be theoretically justified.

${ }^{14}$ For example, in Colombia, a worker is defined as working in the informal sector if his/her employer does not contribute social security taxes into his/her social security fund. In Brazil, the definition of informality is based on whether a worker has a signed work card. A signed worked card entitles the worked to legislated benefits and rights.
} 
13 percent less than a worker with the same observable characteristics and industry affiliation in the formal sector (depending on a year). Of course, one cannot interpret this negative association between work in the informal sector and log hourly wages as causal, since people may self-select into the informal sector based on unobservable characteristics that also independently affect wages. Moreover, the claim that informal jobs are of lower quality and less desirable is controversial. For example, individuals that value flexible hours might consider informal work arrangements superior to formal ones and might voluntarily seek informal jobs. A special module on Quality of Employment from 1994 Colombian National Household Survey contains various questions about job satisfaction and work conditions that yield several descriptive statistics about the quality of jobs in the formal and informal jobs as perceived by the workers. These statistics suggest that workers in the informal sector are more likely to be less satisfied with working conditions, employee relations, job characteristics, and are much less likely to report receiving any benefits than formal workers (Goldberg and Pavcnik (2003)).

We should emphasize that unskilled workers are more likely than skilled workers to participate in the informal sector. In Colombia for example, workers with complete secondary or university education are less likely to work in the informal sector than less educated workers, conditional on other worker characteristics and industry of employment (Table 4b, Goldberg and Pavcnik (2003)). Similarly in Brazil, workers with complete university degree are less likely to participate in the informal sector than less educated workers (Table 4a, Goldberg and Pavcnik (2003)). Of course, people may self-select into the informal sector based on unobservable characteristics that also independently affect educational attainment. Nevertheless, this evidence suggests that the informal sector disproportionately employs less educated workers, who are more likely positioned towards the bottom of the wage distribution. Because workers in the informal sector earn lower wages than workers with the same observable characteristics in the formal sector, unskilled (i.e., less educated) workers receive lower wages than skilled workers not only because of the increase in the skill premium, but also because they are disproportionately employed in the informal sector.

Overall, while the above evidence is only descriptive, it is consistent with the view that the informal sector employs a disproportionate share of unskilled workers and is associated with lower quality jobs. Thus, trade liberalization could at least in principle lead to greater inequality if tariff cuts are associated with increased probability of working in the informal sector. 
The evidence on whether declines in tariffs are associated with increases in probability of informal work is mixed. Currie and Harrison (1997) find that public-sector firms hire a greater share of temporary workers following a trade liberalization episode in Morocco. Goldberg and Pavcnik (2003) find that conditional on worker observable characteristics, tariff declines are not associated with increases in probability of working in the informal sector in Brazil. However in Colombia, where labor markets are believed to be more rigid than in Brazil (Heckman and Pages (2000)), they find a negative association between tariffs and the probability of working in the informal sector, but only for the period preceding the labor market reform that increased the flexibility of hiring/firing a worker.

In sum, the evidence suggests that trade liberalization could contribute to inequality by increasing the probability of working in the informal sector. However, this evidence is not very robust across countries and time. One potential explanation for the differences in the findings across markets lies in labor market institutions. The differences between the findings for Brazil and Colombia, and the differences in the response of the informal sector to tariff cuts in Colombia before and after the labor market reform in particular are consistent with the view that firms are more likely to react to increased market competition by reductions in the formal employment when they operate in more rigid labor market.

Differences in labor market rigidities could stem from several sources. In the case of Brazil and Colombia, differences in the costs of dismissing a worker (such as severance payments) may provide part of the explanation for the different findings concerning the effects of trade reform on informality. These costs are significantly higher in Colombia than in Brazil throughout the 1980's and 1990's, and they are higher in Colombia before the 1990 labor market reform than in the late 1990's (see Goldberg and Pavcnik (2003), pages 477-78 for details). Other labor market institutions such as unions could in principle also play a role. Unfortunately, the evidence on unionization rates and union bargaining power is mostly anecdotal, because information on union membership is not available at the individual level (or even the industrylevel) for Colombia, and it is available only in some years and data sets for Brazil. This makes any attempt to link labor market rigidities to unions empirically evasive. Nevertheless, we are not aware of any claims suggesting that union power has changed during the reform period in Colombia and that this change could explain the differences in our findings before and after the labor market reform. 
Obviously, a further examination of the interactions between labor market institutions, trade reform, and informality remains an important topic for future research. Such research would be especially valuable if it relied on micro survey data from within a country in a setting where labor market institutions vary across administrative units as Besley and Burgess (2004) and Aghion, Burgess, Redding, and Zilliboti (2003) have done in their studies of the effects of labor market institutions on growth and productivity in the case of India.

\subsection{Other Channels Suggested by Recent Theoretical Studies}

Motivated by the empirical finding of rising inequality in both the North and South, a number of recent theoretical studies have developed models aimed at explaining this increase. Banerjee and Newman (2004) develop a model in which trade patterns and the effects of trade liberalization on the income distribution depend on the degree of capital market imperfections. An appealing feature of the model is that, just like the specific factors model, it yields clear empirical predictions concerning the short- and medium-run adjustment to trade reforms. The challenge from an empirical point of view is to find variables that could accurately capture the "quality" of capital market in the relevant countries.

Xu (2002) develops a model with endogenously traded goods, in which the effects of trade liberalization on inequality in developing countries is U-shaped; for initially high levels of protection, trade liberalization reduces inequality, while for subsequently lower levels of protection, trade liberalization increases inequality. The mechanism through which these effects operate is a trade-liberalization induced decrease in the range of non-traded goods. This decrease can produce ambiguous effects on the relative wages of unskilled workers depending on the initial level of trade protection.

As mentioned above, while the ideas put forward in these models are interesting, empirical support for them is still pending. Further empirical work is needed in order to assess the relevance of the competing hypotheses put forward for explaining the rise in inequality in particular countries.

\section{Trade Liberalization and Poverty}


As discussed in section 2, establishing a link between intertemporal variation in trade policy measures and an aggregate poverty measure is a difficult task. Perhaps a more manageable approach is to relate changes in trade policy to particular phenomena that are highly correlated with poverty. To this end, it is instructive to first understand through which channels poverty can be affected.

Trade policy affects household welfare through three main channels: the participation and earnings of household members in labor markets, household consumption, and household production. ${ }^{15}$ Most empirical studies to date have adopted a partial-equilibrium approach, focusing on one channel, or one particular component of a channel, at a time. While the obvious limitation of this approach is that it ignores general equilibrium effects, and hence cannot offer conclusive evidence as to how poverty is ultimately affected, its appeal lies in its tractability and the credibility of the empirical findings. Most of our discussion will therefore focus on such partial-equilibrium studies, organizing them according to the channel through which poverty is in each case potentially affected. We will however refer to one recent empirical study (Porto (2004a)) that employs a general-equilibrium approach to illustrate how labor market and consumption effects work together to affect poverty. As in the previous section, our focus will remain on short- and medium-run, static, effects that are empirically more tractable, than longrun dynamic effects, operating through growth.

\subsection{Partial Equilibrium Studies: Labor Markets Channel}

Most of the existing research on the relationship between trade policy and poverty focuses on the role of labor markets via wages and participation. In particular, trade policy has been occasionally blamed for increases in unemployment, changes in the wage distribution that may hurt the poor, and a "race to the bottom" that manifests itself in lower compliance with labor market standards, more extensive use of part-time and temporary labor, and generally a decrease in the job quality of those who remain employed. In the following, we review the evidence on each of these issues.

\footnotetext{
${ }^{15}$ Trade liberalization could also affect poverty by changing government revenue and government transfers to the poor. We abstract from this channel since there is no empirical evidence based on micro data on the topic. See Winters, McCulloch, and McKay (2004, pp. 103-106) for a discussion of this channel.
} 


\section{(1) Trade policy and unemployment}

Given that the main trade liberalization episodes of the last two decades were concentrated in the manufacturing sectors of developing countries, perhaps the most important way through which trade policy could affect the urban poor in the short- and medium-run, is through an increase in unemployment. Although the concern about unemployment in the aftermath of trade reforms fairs prominently in the public debate on the pros and cons of trade liberalization, it is almost absent in the mainstream models of international trade, which typically assume full employment. ${ }^{16}$ However, when labor markets are characterized by rigidities (as is often the case with developing countries), trade policy changes can lead to transitional unemployment (see Matusz and Tarr (1999) for a discussion).

Unfortunately, on the empirical side, little is known on how changes in trade policy affect the probability and duration of transitional unemployment. Existing empirical research on worker displacement has focused exclusively on the United States, where data from the Displacement Worker Surveys allow one to track the experience of displaced workers (see for example L. Kletzer (1998, 2003)). Even in this case the evidence is only suggestive, as one cannot know with certainty whether it was trade-related factors that ultimately led to a worker's displacement. However, the surveys do report the sector of prior employment, so that it is possible to examine whether workers employed in sectors facing more intense import competition are more likely to lose their jobs. Using this approach Kletzer infers that higher import competition contributes to unemployment (see Kletzer 1998, 2003). Moreover, she finds no evidence that displaced workers get re-employed in export-oriented sectors. These findings have potentially important implications for poverty, especially since import competing industries in the U.S. employ a disproportionate share of unskilled workers.

Establishing a clear link between transitional unemployment and trade liberalization is substantially harder in developing countries, where worker displacement surveys usually do not exist. While some countries have experienced an increase in unemployment following trade reforms, this increase is often attributed to macroeconomic recessions rather than trade policy. In general, there is very little evidence on the link between trade policy and probability (or

\footnotetext{
${ }^{16}$ A notable exception is the work of Neary $(1978,1982)$ that explores the consequences of factor specificity in the short run. In Neary's framework it is possible that factor markets are at disequilibrium in the short run as the economy adjusts to a terms-of-trade shock.
} 
duration) of unemployment. Attanasio, Goldberg, and Pavcnik (2004) examine whether the increase in the probability of being unemployed was greater for workers in the manufacturing sector (where tariff cuts were the largest) than for workers with the same observable characteristics in non-traded-good sectors (such as wholesale and retail trade, restaurants, hotels, construction, etc.) in urban Colombia. They find that increases in the probability of unemployment before and after tariff reductions were not larger in manufacturing than in nontraded sectors. However, this evidence is based on a very aggregate industry definition, while the information on unemployment is not directly linked to changes in trade policy. Moreover, no attempt is made to link changes in probability of unemployment to poverty.

The difficulty in relating transitional unemployment to trade policy changes stems from the fact that household surveys in developing countries either do not report in which industries the currently unemployed used to work, and in which industries they seek new employment, or when they do contain this information - they report the industry at a very aggregate level (1-digit ISIC). As a result, it is not possible to relate industry unemployment to more disaggregate tariff changes. Moreover, empirical work in this area needs to deal with truncation issues, as workers who are employed in any given survey interval, can only be assumed to be employed up to the end of the particular survey interval, and, similarly, unemployed workers can be assumed to be unemployed only to the extent that they have not found a new job before the end of that survey period. Despite these difficulties, a better understanding of the empirical relationship between trade policy changes and transitional unemployment is essential for assessing the effects of trade liberalization on the "poor", many of which - at least in urban areas- are likely to be unemployed.

\section{(2) Economy-wide changes in the wages of unskilled labor}

Within the set of employed workers, it is plausible to assume that unskilled workers are more likely to be "poor" compared to skilled workers. Under this assumption, trade policy will affect poverty through the same mechanisms it affects wage inequality between skilled and unskilled workers, as long as these mechanisms deliver clear predictions on how trade policy affects the absolute demand (and thus absolute wages) for unskilled workers. Since the previous section discusses these mechanisms and related empirical evidence in detail we abstract from 
them in our discussion on poverty. Of course one of the main determinants of absolute demand for all workers is growth; but, as pointed out above, this is a channel we want to abstract from in the current study.

Nevertheless, we should emphasize three caveats. First, higher wage inequality is not necessarily associated with lower wages for unskilled workers, since trade policy could, in principle, increase the relative demand for skilled workers without lowering the absolute demand for unskilled workers. Second, since the main goal of most existing studies is to evaluate the relevance of trade-related explanations for the increase in wage inequality, the implications of the models for absolute wages of unskilled workers are rarely empirically examined. ${ }^{17}$ The empirical findings might thus not be pertinent to the trade policy and poverty debate. Third, even if trade liberalization is associated with declines (increases) in absolute wages of unskilled workers, these wage declines (increases) may not necessarily translate into higher (lower) poverty. The poverty-implications of the changes in unskilled wages will depend on the position unskilled wage earners in the country's income distribution. Moreover, they will depend on how the prices of consumer goods change in response to trade liberalization, and on the shares of different goods in the consumption basket of the poor. Unfortunately, most of the existing studies abstract from these issues. ${ }^{18}$ Establishing a clear link between the wages of unskilled workers and poverty is further complicated by the fact that due to data limitations empirical studies often restrict themselves to formal workers in the manufacturing sector.

\section{(3) Industry Wages}

Just as increased inequality between skilled and unskilled workers can be associated with increased poverty of unskilled workers (in the absolute sense of poverty), a trade-reform-induced increase in the inequality between workers employed in different industries can lead to an increase in the poverty rate among workers employed in industries that experienced the largest declines in industry wage premiums. A necessary condition for this to happen is that the increase in inequality is not accompanied by an increase in the absolute demand for workers in these sectors that could potentially neutralized the increase in inequality, but such an increase seems

\footnotetext{
${ }^{17}$ Verhoogen (2004) is an exception.

${ }^{18}$ A notable exception is Porto (2004a) that we refer to in detail in a subsequent section.
} 
unlikely in the short run. As shown in the previous section, trade liberalization in many developing countries was indeed concentrated on sectors that had lower wages to start with, and employed more unskilled workers who were more likely positioned close to the bottom of the income distribution (at least among the employed). Thus, trade liberalization could have at least in principle contributed to an increase in poverty.

\section{(4) Trade policy and compliance with labor market standards}

The opponents of globalization often claim that globalization may elevate poverty by reducing firms' compliance with labor standards and increasing the informal sector of the economy. ${ }^{19}$ Alternatively, these firms might circumvent labor market regulation by outsourcing their activities to smaller, informal firms.

If the informal sector is associated with lower wages and if trade increases the probability of working in this sector, trade liberalizations could in principle be associated with increased poverty. Although our discussion in section 3.3 suggests that workers with the same observable characteristics in general earn less in the informal than formal sector, the evidence on the effects of trade policy on the size of the informal sector is mixed.

Moreover, labor market institutions such as the minimum wage are more likely to be binding for the individuals at the bottom of the wage distribution. If greater trade were associated with lower compliance with minimum wage laws, greater trade could increase poverty. Harrison and Scorse (2004a) investigate whether exporters and foreign-owned firms are more or less likely to comply with minimum wage legislation than domestic firms using plant-level data from the annual survey of manufacturers in Indonesia covering 1990-1999. During this period, Indonesia experienced increases in the legislated minimum wage that differed across regions and time. Harrison and Scorse (2004a) measure compliance with minimum wage laws with an indicator for whether the average wages of production workers in a plant are above the legislated minimum wage. Their findings suggest that conditional on worker and plant characteristics, foreign-owned firms are associated with higher compliance than domestic firms. Interestingly, while average wages of production workers are less likely to exceed the minimum wage in

\footnotetext{
${ }^{19}$ Note that this argument is conceptually different from the argument that globalization leads to race to the bottom in labor standards by forcing competition among governments to offer an attractive business environment.
} 
exporting than domestic plants at the beginning of the sample, exporting plants are more likely to comply in the latter part of the sample. The authors propose that this change is consistent with increased activism of human rights groups in Indonesia during the late 1990s.

In a subsequent paper Harrison and Scorse (2004b) examine the latter point more directly by checking whether the wage growth of production workers during this period differs across firms in sweatshop industries (i.e., textiles, apparel, and footwear (TFA)) and non-TFA firms. TFA firms are a common target of human rights activists and are thus potentially more likely to comply with minimum wage regulation than non-TFA firms. Their results suggest that wages of production workers grow faster in foreign-owned and exporting firms in TFA industries than in other firms. When they repeat their analysis for wages of nonproduction workers (for whom minimum wage laws are less likely to be binding), no such pattern exists. It seems thus unlikely that the results for production workers simply reflect unobserved firm heterogeneity or differential demand shocks across foreign-owned/exporting TFA plants and other plants.

While the existing evidence is consistent with the claim that foreign-owned plants are not associated with lower compliance with minimum wages, several questions remain open for future research. First, an alternative mechanism through which firms might avoid paying minimum wages (or comply with other labor market standards) is outsourcing within a host country. Many activists assert that foreign-owned firms circumvent labor market standards by outsourcing low-wage activities to small domestic firms that are under lower scrutiny of humanrights activists. In fact, Harrison and Scorse (2004b) present some evidence that is consistent with this view. Investigating the importance of this mechanism might be a fruitful research agenda for future work. Second, when labor market standards differ across countries, firms might choose to reallocate their activities to markets with lower labor market standards. Some recent evidence is consistent with the footloose image of multinational firms: conditional on firm characteristics, foreign-owned plants are associated with greater probability of shutting down than domestic plant in the United States (Bernard and Jensen (2003) and in Indonesia (Bernard and Sjoholm (2003)). Moreover, Harrison and Scorse (2004b) find that large TFA exporters were more likely to shut down their operations in Indonesia during the intensified anti-sweatshop activity. Disentangling whether differences in labor market standards play a role in these shutdown decision and whether differences in labor market standards can explain subsequent new operations in other markets remains an open question. 
In sum, the existing empirical evidence suggests that liberalized trade policy or foreigndirect investment are not necessarily associated with an increase of the informal sector or lower compliance with minimum wages. Yet, many questions remain open for future research. We should emphasize, though, that even if trade liberalization was associated with an increase in the informal sector (or greater noncompliance with labor market standards), this would not necessarily imply an increase in poverty, if, for example, the individuals who reallocated to the informal sector, or were paid wages below the minimum wage, would have otherwise become unemployed.

\section{(5) Child Labor}

A highly visible component of the debate on the effects of trade reforms on the world's poor is the role of trade policy for child labor in developing countries. Abolition of child labor is one of the four ILO's core labor standards. Child labor may not only be associated with lower welfare for the working children, it may also lead to intergenerational transmission of poverty if it interferes with human capital accumulation. The opponents of globalization argue that increases in product-demand induced by trade liberalization may rise the earnings opportunities of children in poor economies, thereby increasing child labor. Others point out that liberalized trade and increased access to world markets could help eradicate child labor by raising the standard of living. Both of these claims are consistent with the predictions of theoretical models of child labor. Trade liberalization could either increase or decrease child labor depending on whether greater demand for child labor stemming for trade (i.e., the substitution effect) outweighs the reduced supply of child labor in cases where trade liberalization is associated with increases in household income and child labor is a bad in parental preferences or households are credit constrained (i.e., the income effect). ${ }^{20}$

Edmonds and Pavcnik (2004b) study the effect of trade liberalization on the incidence of child labor in rural Vietnam using information on child labor from the Vietnamese Living Standard Surveys from 1992/93 and 1997/98 that span the period of national and international rice market liberalization during the 1990s. Since theory predicts that product market

\footnotetext{
${ }^{20}$ Edmonds and Pavcnik (2004a) provide an overview of the mechanisms and predictions of various theoretical models in detail.
} 
liberalization affects domestic labor markets through changes in relative product prices, they relate child labor to regional and intertemporal variation in rice prices and address the endogeneity of price changes by inclusion of various region-time specific controls that could in principle yield spurious correlation between child labor and prices. The results suggest that on average, higher rice prices are associated with lower child labor. In particular, a 30\% increase in the real price of rice (as observed in Vietnam during this period) is associated with a 9 percentage point decline in child labor. Income effects seem to play an important role in this relationship. Higher rice prices are associated with greater declines in child labor in net-rice producing households, while child labor actually increases in household that are large netconsumers of rice. ${ }^{21}$ Interestingly, the magnitude of the income effect is large enough so that rice price increases are associated with declines in child labor in agriculture in households that are large-net producers of rice.

Several questions remain open for future research. In particular, how price changes affect child labor depends on country-specific characteristics such as the distribution of resources used in the liberalized sectors across households, the sign of the price effect, and the relative strength of the income and substitution effects. For example, in the case of Vietnam, land is very equitably distributed across households, so that many households were well positioned to gain as net rice producers from higher rice prices and thus benefit via the income effects of rice price changes. The income effects associated with trade reform might not be as pronounced in other settings. Second, regional and intertemporal variation in prices within a country that spans a liberalization episode provides an attractive setting to study the implications of trade reforms for child labor or other labor market outcomes (as long as one controls for other region-specific time varying factors that could lead to spurious correlation between prices and outcomes of interest). However, future work on child labor needs to establish a tighter link between exogenous trade policy changes and regional price variation within a country. ${ }^{22}$

To conclude, most of the existing evidence on the link between trade policy and "poverty" has focused on how trade policy affects household poverty through labor market outcomes. The existing work has not provided a clear message as to whether trade liberalization has contributed to phenomena that we typically associate with higher probability of poverty

\footnotetext{
${ }^{21}$ Household net-production and consumption is defined based on pre-liberalization information.

${ }^{22}$ Similarly, Winters, McCulloch, and McKay (2004) emphasize the importance of understanding how international shocks are transmitted to producers and consumers within a country in trade and poverty analysis.
} 
(such as unemployment, informality, unskilled labor wages, child labor, etc.). The connection to a poverty increase (or reduction) is naturally even more tenuous.

\subsection{Partial Equilibrium Studies: Household Consumption and Production}

The analysis of how trade policy affects poverty via the consumption channel has been mostly neglected in the empirical work by trade economists. This is not surprising: trade models in general assume identical and homothetic preferences across individuals and countries (Hunter and Markusen (1988), Mitra and Trindade (2003) are exceptions). In this setting, trade-induced relative price changes affect all individuals through the consumption channel equally in proportional terms and do not alter the distribution of real income in an economy. While this assumption about preferences may be innocuous in models whose main aim is to explain patterns of trade and their welfare implications based on supply-side differences across countries, relaxing this assumption is critical in studies of the effects of trade policy on poverty. For example, Engel's law suggests that poor individuals spend a higher share of their budget on food items. Thus, trade-induced price changes likely affect individuals in the bottom and top of household expenditure distribution differentially via the consumption channel.

Similarly, most work on the effect of trade policy on poverty focuses on formal workers (often in manufacturing). While this emphasis might not be too problematic in studies of trade reforms on urban sectors in middle income countries, only a small share of individuals participate in labor markets as wage earners in poorer economies. Instead, many of them are self-employed on a family farm, family business, or work in non-traded household activities. For example, in Vietnam in 1993, only 19 percent of adults ages 20-64 work for wages and only 7 percent work in manufacturing (Edmonds and Pavcnik (2003)). In this setting, how trade liberalization affects household welfare via production activities depends on a household's exposure to trade-induced price changes as sellers of goods. Accounting for these effects is likely most relevant in rural settings and in studies of agricultural trade liberalizations.

Deaton (1989) provides a nonparametric empirical methodology that uses the information on the patterns of demand and supply of a commodity to investigate the impact of small changes in prices (potentially stemming from trade policy changes) on household welfare via household consumption and production along the entire household per capita expenditure 
distribution. ${ }^{23}$ This analysis requires cross-sectional information on household expenditures and household production, often available in Living Standard Measurement Surveys. Deaton (1989) shows that the difference between the household's value of production and the value of consumption of a particular good (as a share of household expenditures) is the negative of its elasticity of its cost of living with respect to the price of this good. This is called the benefit/expenditure ratio. Since households in various parts of welfare distribution differ in their production and consumption patterns, a convenient way to analyze the distributional consequences of changes in prices is by nonparametrically estimating average net benefit ratio at all point of per capita expenditure distribution. This expected benefit ratio shows the distributional effect of price changes. An increase in the price of the commodity will enhance (reduce) the welfare of net producing (consuming) households.

Accounting for the consumption effect and allowing for differences along the household expenditure per capita distribution turns out to matter. This is best demonstrated in a recent empirical study by Porto (2004a) that employs a general equilibrium framework to address both labor market and consumption effects that we discuss in the next section. Similarly, Deaton (1989) and Benjamin and Deaton (1993) study the distributional effects of price changes on household welfare via the production channel along the household per capital expenditure distribution. They convincingly show that this analysis can be a powerful tool in identifying which households, in which part of the income distribution, may benefit/suffer the most from policy induced price changes. These tools may thus prove useful in studying the welfare implications of future agricultural trade reforms.

\subsection{A general equilibrium approach}

Porto (2004a) develops an ambitious empirical framework to study the impact of trade on poverty. This framework incorporates household heterogeneity in a general equilibrium model of trade. Households earn income as skilled and unskilled laborers and derive utility from consumption of traded and non-traded goods. Trade policies affect prices of consumption goods and wages, which in turn affect household living standards via consumption and labor income

\footnotetext{
${ }^{23}$ The methodology abstracts from substitution effects of price changes in consumption and production. If the substitution elasticities do not differ across households in different parts of per capita expenditure distribution, this abstraction is unlikely to affect the distributional consequences of price changes (see Deaton (1989)).
} 
effects. The model can be used to simulate the effects of trade policy changes on household wellbeing along the entire distribution of expenditure per capita across households by extending techniques in Deaton (1989) described above. ${ }^{24}$

Porto applies this approach to study the effect of Argentina’s entrance to Mercosur on welfare of urban Argentine households. He finds that Mercosur has pro-poor effects via the labor income channel that are consistent with the Stolper-Samuelson mechanism. Because Mercosur-induced tariff cuts were greater in skilled-labor intensive sectors, the structure of the model implies that prices of unskilled-labor intensive sectors such as food and beverages increase, while prices of skilled-labor intensive good such as household equipment decline. Based on the estimates of wage-price elasticities obtained from the household labor surveys, these price changes translate into increased wages of unskilled workers and declines in wages of skilled workers. Because households at the bottom of per capita expenditure distribution are relatively better endowed with unskilled labor, they benefit via labor income channel, while households at the right tail of the household per capita expenditure loose. The labor-income gains to the poor and middle-income households amount to about $7 \%$ of their initial household expenditure while losses to the rich households can amount to up to $5 \%$ of the initial household expenditure. The analysis thus suggests that Mercosur is associated with poverty declines in urban Argentina via the labor income channel.

Regarding the consumption channel, two interesting findings emerge. First, the consumption effects have a pro-rich bias. This is due to the fact that the model predicts that prices of unskilled-labor intensive food and beverages actually increase with Mercosur's tariff reductions and poorer households spend a large share of their budget on this category. On the other hand, the model predicts declines in prices of non-traded goods such as health and

\footnotetext{
${ }^{24}$ Porto (2004a) extends the analysis to study distributional effects of trade reforms via labor market income. He shows that the effect of a small trade-policy-induced price change on the household labor income is given by the product of the wage-price elasticity, the price change, and the share of individual i's wage earnings in total household earnings (summed over all working individuals). The data and parameter estimates required for the analysis are obtained as follows. First, household budget shares and labor income shares are calculated from household expenditure surveys and labor force surveys, respectively. Second, the trade-induced changes in prices of internationally traded goods are calculated based on negotiated changes in product tariffs under the assumption of complete pass-through. Third, time-series information on goods prices is used to estimate the elasticities of skilled and unskilled wages with respect to prices of traded goods using typical earnings regressions and exploiting timeseries variation in wages and prices of traded goods. Trade-induced changes in prices of non-traded-goods are estimating by a time-series regression of prices of each non-traded good on prices of all traded goods. Note that this analysis does not require household survey information and price information that spans trade liberalization episodes. Thus, the framework can also be used to study the impact of hypothetical price changes, motivated by a policy concern (see Porto (2004b, 2004c) as examples).
} 
education and leisure goods and the budget shares of these goods increase with per capita household expenditure. Thus, abstracting from consumption channel overstates pro-poor bias of Mercosur via labor income. The question then becomes whether consumption effects are large enough to offset the labor income effects. Interestingly, the magnitude of the consumption effect is in general much smaller than the magnitude of labor income effects. The consumption effects via traded goods range from declines in a living standard of the very poor by .5\% of initial household expenditure to increases in living standards of the richest households by .75\% of the initial household expenditure. The corresponding numbers for the consumption effects via the non-traded goods are .3\% to just over $1 \%$ of initial household income. In some cases, these effects are almost an order of magnitude smaller than the welfare changes associated with labor market income previously discussed. Porto attributes the relatively small magnitudes of the consumption effect relative to the labor income effect to magnification effects of goods prices to factor prices within a Hecksher-Ohlin model ala Jones (1965). In general, the importance of consumption channel will likely depend on the nature of trade reform and the consumption channel might be more important in liberalizations that focus on agricultural products.

This approach has several appealing features. First, it analyzes the effects of trade policy in a general equilibrium setting. This is especially valuable in instances when general equilibrium effects on wages and consumption are expected to be large (for example, via changes in tariffs in other sectors due to intermediate good linkages or changes in prices of nontraded goods), or when one is interested in the overall effect of trade reform (rather than its impact on wages via a particular channel - the focus of most of the partial equilibrium work). Understandably, the general equilibrium analysis comes at a cost of aggregation of sectors of the economy. Second, unlike previous work, the framework considers how trade policy affects poverty via the consumption channel. Third, since the framework allows for households in different parts of the distribution to differ in the composition of consumption and endowments of skilled and unskilled labor, price changes can exert differential effect household welfare along the entire distribution of household per capita expenditures. Fourth, this approach enables a study of implications of trade policy on poverty when household level data that spans the trade liberalization episode is not available. ${ }^{25}$

\footnotetext{
${ }^{25}$ The analysis requires cross-sectional data on household expenditures and labor income to obtain labor income shares and budget shares, and repeated cross-sectional labor surveys that can be matched to price time-series.
} 
One potential drawback of the method is that its predictions depend heavily on the estimates of the elasticity of price of non-traded goods with respect to traded goods prices and the wage-price elasticities. Since these parameter estimates are not identified based on data that relate plausibly exogenous trade policy variation to household surveys (and price data) spanning the trade reform period, they are unbiased only if the monthly time-series variation in prices of traded goods is exogenous conditional on time trends and year effects. This is potentially a strong assumption.

Moreover, the predictions of the model may be sensitive to the assumption of complete pass-through from trade policy to prices. Empirically, very little is known on how prices respond to tariff changes. This partially reflects data scarcity—tariff changes are relatively rare events and detailed data on industry prices and tariffs surrounding trade liberalization episodes are in many cases not readily available. However, a related literature on how prices respond to exchange rate fluctuations (which are much more common) concludes that pass-through is incomplete depending on factors such the particular industry and country under consideration, etc. (see Goldberg and Knetter (1997)). ${ }^{26}$ This suggests that the assumption of complete passthrough might not be innocuous. Relaxing this assumption and exploring the sensitivity of the results to different pass-through rates may be a useful future extension. ${ }^{27}$

\section{Conclusions}

Despite many measurement and identification difficulties, and despite conflicting empirical evidence on some issues, empirical work on recent trade liberalization episodes has established some patterns that seem common across countries and trade liberalization episodes, and may hence be informative as to how developing countries adjust to trade reform. These can be summarized as follows:

1. The most heavily protected sectors in many developing countries tend to be sectors that employ a high proportion of unskilled workers earning low wages. Accordingly, it should not

\footnotetext{
${ }^{26}$ See Feenstra (1989) on the symmetry between tariff- and exchange rate pass-through.

${ }^{27}$ Porto (2004b), for example, conducts such sensitivity analysis in a different paper and finds that 50\% passthrough leads in general to estimates of welfare changes that can be up to a half the size of the changes obtained under the full pass-through assumption.
} 
come as a surprise if trade liberalization has a negative impact on unskilled workers in the short- and medium-run. If there is a puzzle, this is why most developing countries find it optimal to protect low-skill intensive sectors, when intuitively patterns of comparative advantage would suggest otherwise. Three explanations for this pattern of protection seem apriori plausible. The first one would rely on political economy considerations suggested by Grossman and Helpman (1994) for example. The second explanation would hinge on an extension of Heckscher-Ohlin to a three-factor (natural resources, unskilled, and skilled labor) version along the lines suggested by Wood (1999) and Leamer et al (2002)). Finally, this pattern of protection could also be explained by an extension of the Hecksher-Ohlin model to at least 3 countries that differ sufficiently in their factor endowments so that they partially specialize in various industries (i.e., existence of multiple cones of diversification), and one of these countries (e.g., China) is even more unskilled-labor abundant than the other developing country (e.g., Colombia) (Davis (1996), Wood (1999)). Empirical work to date has not offered a verdict on the relevance of these alternative hypotheses; this is however a fruitful area for future research.

2. Despite the large magnitude of tariff and NTB reductions observed in many developing countries in the 1980’s and 1990's empirical work has consistently documented a lack of major labor reallocation across sectors.

3. There is some evidence that trade liberalization decreased the industry wage premiums in those sectors that experienced the largest tariff reductions. This is consistent with the dissipation of industry rents, or alternatively, the existence of labor market rigidities that constrain labor mobility across sectors in the short and medium run. However, the effects of trade reforms on industry wages are generally estimated to be small.

4. In general, the price (wage) response to trade liberalization is more pronounced than the quantity response. This is again indicative of market rigidities that may be particularly relevant in developing countries in the short run.

5. Given the magnitude of the trade reforms, the effects uncovered by empirical work are small, and can explain only a small fraction of the general increase in wage inequality.

6. Studies using plant- or firm-level data, on the other hand, document substantial output reallocation in the aftermath of trade reforms towards more productive firms within an industry, so that aggregate productivity increases in the industries that liberalized more. 
7. The previous two points taken together suggest that the lack of evidence that trade liberalization had any major effects on the wage distribution may be partly due to the high level of aggregation used in household surveys (2- or 3-digit ISIC). This aggregation level is too coarse to detect worker reallocation across firms within the same industry in response to trade liberalization.

8. Against this background, empirical studies that use more disaggregate data, focusing on the differential effect of trade reforms on firms (possibly belonging to the same 3- or 4-digit ISIC sector), or on compositional changes (e.g., quality upgrading) in the products produced by developing countries seem particularly promising. What is missing from current empirical work is a clear link between such compositional changes and changes in the income distribution.

9. While establishing a clear link between trade liberalization and absolute poverty poses a tremendous challenge, especially in rural areas, documenting the correlation between trade liberalization and certain indicators of urban poverty in the short- or medium-run seems more promising.

10. Existing empirical studies find little support for "race to the bottom" arguments. If anything, there is some evidence that more "openness" increases the level of, and compliance with minimum wages, and reduces child labor.

11. Similarly, there is little evidence that trade reforms are associated with an increase in informal employment and a worsening of working conditions. To the extent that one finds such evidence, it seems to be relevant in settings characterized by severe labor market rigidities. A study of labor market institutions and their interactions with trade policy is therefore essential for understanding the effects of trade liberalization on inequality and poverty.

12. Trade liberalization changes relative prices and is thus likely to affect poverty via the effect of price changes on consumption. Empirical work using simulations suggests that these effects are potentially significant. Yet, work in this area is still at a preliminary stage. Part of the difficulty arises from the fact that little is known about the empirical relationship between trade policy changes and changes in relative prices. 


\section{References}

Acemoglu, D. (2003): Patterns of skill premia. Review of Economic Studies 70, 199-230.

Aghion, P., R. Burgess, S. Redding, and F. Zilibotti (2003): "The Unequal Effects of Liberalization: Theory and Evidence from India,” LSE mimeo. London, UK: LSE.

Anderson, K. (2003): Trade Liberalization, Agriculture and Poverty in Low Income Countries. UNU/WIDER Discussion Paper No. 2003/25.

Attanasio, O., Goldberg P., and N. Pavcnik (2004): "Trade Reforms and Wage Inequality in Colombia,” Journal of Development Economics 74, 331-366.

Attanasio, O. and M. Szekely (2000): "Household Saving in East Asia and Latin America: Inequality Demographics and All That”, in B. Pleskovic and N. Stern (eds.), Annual World Bank Conference on Development Economics 2000. Washington, DC: World Bank.

Benerjee, A. and A. Newman (2004). “Inequality, Growth, and Trade Policy,” MIT mimeo. Cambridge, MA: MIT, June 2004.

Benjamin, D. and A. Deaton (1993): "Household Welfare and the Pricing of Cocoa and Coffee in Cote D'Ivoire: Lessons from the Living Standards Surveys,” World Bank Economic Review 7, 293-318.

Bernard, A. and B. Jensen (1997): "Exporters, Skill Upgrading and the Wage Gap," Journal of International Economics, 42, 3-31.

Bernard, A. and B. Jensen (2003): "Firm Structure, Multinationals, and Manufacturing Plant Deaths,” Tuck School mimeo. Hanover, NH: Dartmouth College.

Bernard, A. and F. Sjoholm (2003): “Foreign owners and plant survival,” NBER Working Paper 10039.

Behrman, J., Birdsall N. and M. Szekely (2000): "Economic Reform and Wage Differentials in Latin America," IADB Working Paper 435. Washington, DC: Inter-American Development Bank.

Besley, T. and R. Burgess (2004). "Can Labor Market Regulation Hinder Economic Performance? Evidence from India,” Quarterly Journal of Economics 119(1), 91-134.

Cragg, M.I. and M. Epelbaum (1996): "Why has wage dispersion grown in Mexico? Is it the incidence of reforms or the growing demand for skills?” Journal of Development Economics, Vol. 51, pp. 99-116.

Currie, J. and A. Harrison (1997): “Trade Reform and Labor Market Adjustment in Morocco" Journal of Labor Economics, Vol. 15, pp. S44-71. 
Davis, D. (1996): “Trade Liberalization and Income Distribution,” NBER Working Paper 5693.

Deaton, A. (1989): "Rice Prices and Income Distribution in Thailand: a Non-parametric Analysis," Economic Journal 99, pp 1-37.

Deaton, A. (2003): "Measuring Poverty in a Growing World (or Measuring Growth in a Poor World),” NBER Working Paper 9822.

Edmonds, E. and N. Pavcnik (2003): “Trade liberalization and the allocation of labor between households and markets in a poor country, Dartmouth College mimeo. Hanover, NH: Dartmouth College.

Edmonds, E. and N. Pavcnik (2004a): "International Trade and Child Labor: Cross-country evidence,” NBER Working Paper 10317.

Edmonds, E. and N. Pavcnik (2004b): “The effect of trade liberalization on child labor,” Journal of International Economics forthcoming.

Erdem, E. and J. Tybout (2004): “Trade Policy and Industrial Sector Responses in the Developing World: Interpreting the Evidence”, in S.M. Collins and D. Rodrik (eds.) Brooking Trade Forum 2003: Washington, DC: Brookings. 1-43.

Feenstra, R. (1989): "Symmetric Pass-Through of Tariffs and Exchange Rates Under Imperfect Competition: An Empirical Test,” Journal of International Economics 27, 25-45.

Feenstra, R. and G. Hanson (1996): “Foreign Investment, outsourcing and relative wages”, in R.C. Feenstra et. al. (eds). Political economy of trade policy: essays in honor of Jagdish Bhagwati: MIT Press, Cambridge, 89-127

Feenstra, R. and G. Hanson (1997): "Foreign direct investment and relative wages: Evidence from Mexico’s maquiladoras,” Journal of International Economics 42, 371-393.

Feenstra, R. and G. Hanson (2003): "Global Production Sharing and Rising Inequality: A Survey of Trade and Wages," in Choi E.K. and J. Harrigan (eds.) Handbook of International Trade. Blackwell: Malden, MA, 146-185.

Feliciano, Z. (2001): "Workers and Trade Liberalization: The impact of trade reforms in Mexico on wages and employment”, Industrial and Labor Relations Review, Vol. 55, No. 1, 95-115.

Fernandes, A.M. (2003): “Trade Policy, Trade Volumes and Plant-Level Productivity in Colombian Manufacturing Industries ”, World Bank mimeo. Washington, DC: World Bank.

Goldberg, P.K. and M. Knetter (1997): “Goods Prices and Exchange Rates: What have we learnt?” Journal of Economic Literature, 35, 1243-72. 
Goldberg, P. and N. Pavcnik (2003): “The Response of the Informal Sector to Trade Liberalization”, Journal of Development Economics, 72, 463-496.

Goldberg, P. and N. Pavcnik (2004): “Trade Protection and Wages: Evidence from the Colombian Trade Reforms”, Journal of International Economics, forthcoming.

Grossman, G. (1984): “International Competition and the Unionized Sector”, Canadian Journal of Economics, 17, No. 3, pp. 541-556.

Grossman, G. (1986). “Imports as a Cause of Injury: The Case of the U.S. Steel Industry,” Journal of International Economics, 20, 201-223.

Grossman, G. and E. Helpman (1994): “Protection for Sale”, American Economic Review, 84(4), 833-850.

Hanson, G. and A. Harrison (1999): “Trade and wage inequality in Mexico,” Industrial and Labor Relations Review 52(2) , 271-288.

Harrison, A. (1994): "Productivity, Imperfect Competition and Trade Reform: Theory and Evidence”, Journal of International Economics, Vol. 36 (1-2), 53-73.

Harrison, A. and G. Hanson (1999): "Who gains from trade reform? Some remaining puzzles”, Journal of Development Economics, Vol. 59, 125-154.

Harrison, A. and J. Scorse (2004a): "The Impact of Globalization on Compliance with Labor Standards: A Plant-Level Study," in S.M. Collins and D. Rodrik (eds.) Brooking Trade Forum 2003: Washington, DC: Brookings, 45-96.

Harrison, A. and J. Scorse (2004b): “Moving Up or Moving Out? Anti-Sweatshop Activists and Labor Market Outcomes,” NBER Working Paper 10492.

Hay, D.A. (2001): "The Post-1990 Brazilian Trade Liberalization and the Performance of Large Manufacturing Firms: Productivity, Market Share, and Profits," Economic Journal 111: 620-641.

Heckman J. and Pages C. (2000): “The Cost of Job Security Regulation: Evidence from the Latin American Labor Market,” NBER Working Paper 7773.

Hunter, L. and J. Markusen (1988): “Per-Capita Income as a Determinant of Trade,” in R.C. Feenstra, (ed.) Empirical Methods for International Trade, MIT Press, Cambridge, MA, 89-109.

Jones, R.W. (1965): "The Structure of Simple General Equilibrium Models," Journal of Political Economy 73, 557-572.

Kim, E. (2000): “Trade Liberalization and Productivity Growth in Korean Manufacturing Industries: Price Protection, Market Power and Scale Efficiency”, Journal of Development Economics, Vol. 62(1), pp. 55-83. 
Kletzer, L. (1998): “International Trade and Job Loss in U.S. Manufacturing, 1979-91,” in Susan M. Collins, ed., Imports, Exports, and the American Worker, Washington, DC, The Brookings Institution, pp. 423-472.

Kletzer, L. (2003): “Trade-related Job Loss and Wage Insurance: A Synthetic Review,” Review of International Economics, forthcoming.

Krishna, P. and D. Mitra (1998): “Trade Liberalization, Market Discipline and Productivity Growth; New Evidence from India”, Journal of Development Economics, Vol. 56(2), pp. 447462.

Leamer, E. (1998): "In search of Stolper-Samuelson Effects on U.S. Wages,” in S. Collins, (ed.), Exports, imports and the American worker. Washington DC: Brookings, 141-214.

Leamer, E., H. Maul, S. Rodriguez, and P. Schott (2002): “Does Natural Resource Abundance Cause Latin American Inequality?” Journal of Development Economics, 59(1), pp. 3-42.

Levinsohn, J. (1993). “Testing the Imports-as-Market-Discipline Hypothesis,” Journal of International Economics, 35(1-2), 1-22.

Marcouiller, D., V. Ruiz de Castilla, and C. Woodruff (1997): "Formal Measures of the InformalSector Wage Gap in Mexico, El Salvador, and Peru," Economic Development and Cultural Change, 45:2, pp. 367-392.

Matusz S. and D. Tarr (1999): “Adjusting to Trade Policy Reform,” World Bank Policy Research Working Paper 2142.

Melitz, M. (2003). “The Impact of Trade on Intra-industry Reallocations and Aggregate Industry Productivity,” Econometrica 71, 1696-1725.

Mistiaen, J.A. and M. Ravallion (2003). "Survey Compliance and the Distribution of Income," Policy Research Working Paper 2956. World Bank, Washington DC.

Mitra, D. and V. Trindade (2003): “Inequality and Trade,” NBER Working Paper 10087.

Muendler, M. A. (2004): “Trade, Technology, and Productivity: A Study of Brazilian Manufacturers, 1986-1998”, University of California, San Diego mimeo.

Neary, P. (1978): "Short-run capital specificity and the pure theory of international trade," Economic Journal, 88, September 1978, pp. 488-510.

Neary, P. (1982): “Intersectoral capital mobility, wage stickiness and the case for adjustment assistance,” in J.N. Bhagwati (ed.): Import Competition and Response, Proceedings of NBER Conference, Chicago: Chicago University Press, 1982, pp. 39-67. 
Pavcnik, N. (2002): “Trade Liberalization, Exit and Productivity Improvements: Evidence from Chilean Plants”, Review of Economic Studies, 69 pp. 245-76.

Pavcnik, N. (2003): “What explains skill upgrading in less developed countries?” Journal of Development Economics, 71, 311-328.

Pavcnik, N., A. Blom, P.K. Goldberg, and N.Schady (2004). “Trade Policy and Industry Wage Structure: Evidence from Brazil,” World Bank Economic Review, forthcoming.

Porto, G. (2004a): “Using Survey Data to Assess the Distributional Effects of Trade Policy,” World Bank mimeo. Washington, DC: World Bank.

Porto, G. (2004b): “Informal Export Barriers and Poverty,” World Bank mimeo. Washington, DC: World Bank.

Porto, G. (2004c). “Market Access and Poverty in Argentina,” World Bank mimeo. Washington, DC: World Bank.

Ravallion, M. (2003): “The Debate on Globalization, Poverty, and Inequality: Why Measurement Matters,” World Bank Policy Research Working Paper 3038. Washington, DC: World Bank.

Revenga, A. (1992): "Exporting Jobs? The Impact of Import Competition on Employment and Wages in U.S. Manufacturing”, Quarterly Journal of Economics, 107(1), pp. 255-284.

Revenga, A. (1997): "Employment and wage effects of trade liberalization: The Case of Mexican Manufacturing”, Journal of Labor Economics, Vol. 15, pp. S20-43.

Robbins, D. (1996): “Evidence on Trade and Wages in the Developing World,” OECD Technical Paper No. 119.

Robertson, R. (2000): "Trade Liberalization and Wage Inequality: Lessons from the Mexican Experience,” World Economy 23, 827-849.

Robertson, R. (2004): “Relative prices and wage inequality: evidence from Mexico,” Journal of International Economics forthcoming.

Sanchez-Paramo, C. and N. Schady (2003): “Off and Running? Technology, Trade, and the Rising Demand for Skilled Workers in Latin America,” World Bank Policy Research Working Paper 3015.Washington, DC: World Bank.

Schott, P. (2004): “Across-Product versus within-product specialization in international trade,” Quarterly Journal of Economics 119, 647-678.

Szekely and Hilgert (1999): "What's Behind the Inequality we Measure: An Investigation Using Latin-American Data”, IADB Working Paper 409. Washington, DC: Inter-American Development Bank. 
Thoenig, M., Verdier, T., (2003): "A theory of defensive skill-based innovation and globalization.” American Economic Review 93, 709-728.

Topalova, P. (2004): “Trade Liberalization and Firm Productivity: The Case of India,” IMF Working Paper 04/28. Washington, DC: IMF.

Verhoogen, E. (2004): “Trade, Quality Upgrading and Wage Inequality in the Mexican Manufacturing Sector: Theory and Evidence from an Exchange-Rate Shock,” University of California, Berkeley mimeo.

$\mathrm{Xu}$, B. (2002): “Trade liberalization, wage inequality, and endogenously determined non-traded goods,” Journal of International Economics 60, p. 417-431.

Wacziarg, R. and J. Seddon Wallack (2004): “Trade liberalization and Intersectoral labor movements,” Journal of International Economics forthcoming.

Winters, A., N. McCulloch, and A. McKay (2004): “Trade Liberalization and Poverty: The Evidence so Far,” Journal of Economic Literature 62, 72-115.

Wood, A. (1995): “How Trade Hurt Unskilled Workers”, Journal of Economic Perspectives, 9(3), pp. 57-80.

Wood, A. (1999): “Openness and Wage Inequality in Developing Countries: The Latin American Challenge to East Asian Conventional Wisdom”, in: Baldwin, R. et-al. (eds.) Market integration, regionalism and the global economy, Cambridge: Cambridge University Press, pp. 153-181.

World Bank (2000). World Development Report 2000/2001. Attacking Poverty. New York: Oxford University Press.

World Bank (2002). Colombia Poverty Report. Volume 1: Main Report. Report No. 24524-CO. Washington, DC: World Bank. 
Figure 1—Colombian Industry Tariffs in 1984 and 1998

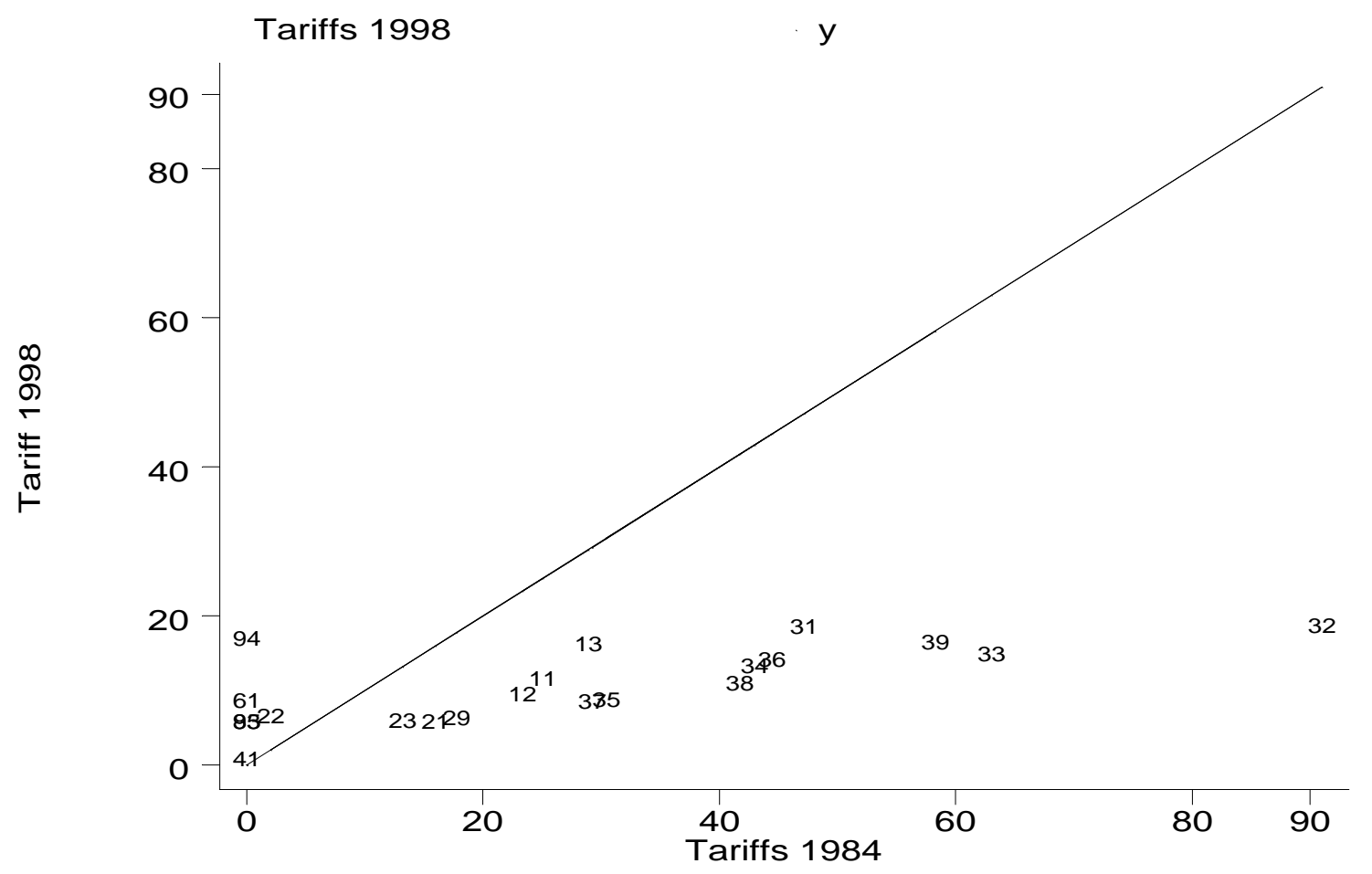

Note: The line is a 45-degree line. The numbers represent 2-digit ISIC codes.

Source: Goldberg and Pavcnik (2004). 
Figure 2--Tariff Decline in Colombia1998-1984 and Pre-Reform Tariffs

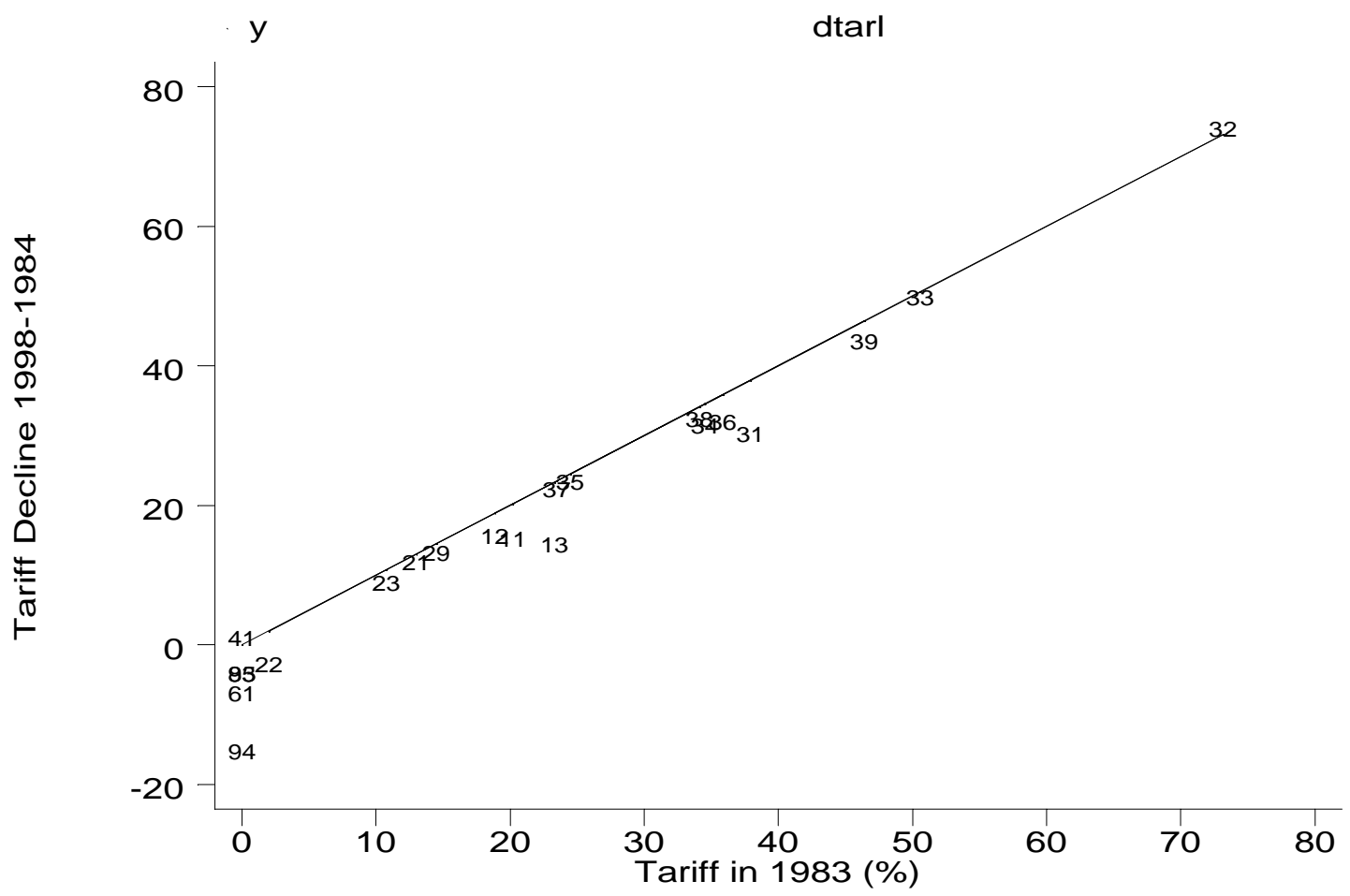

Note: The line is a 45-degree line. The numbers represent 2-digit ISIC codes.

Source: Goldberg and Pavcnik (2004). 